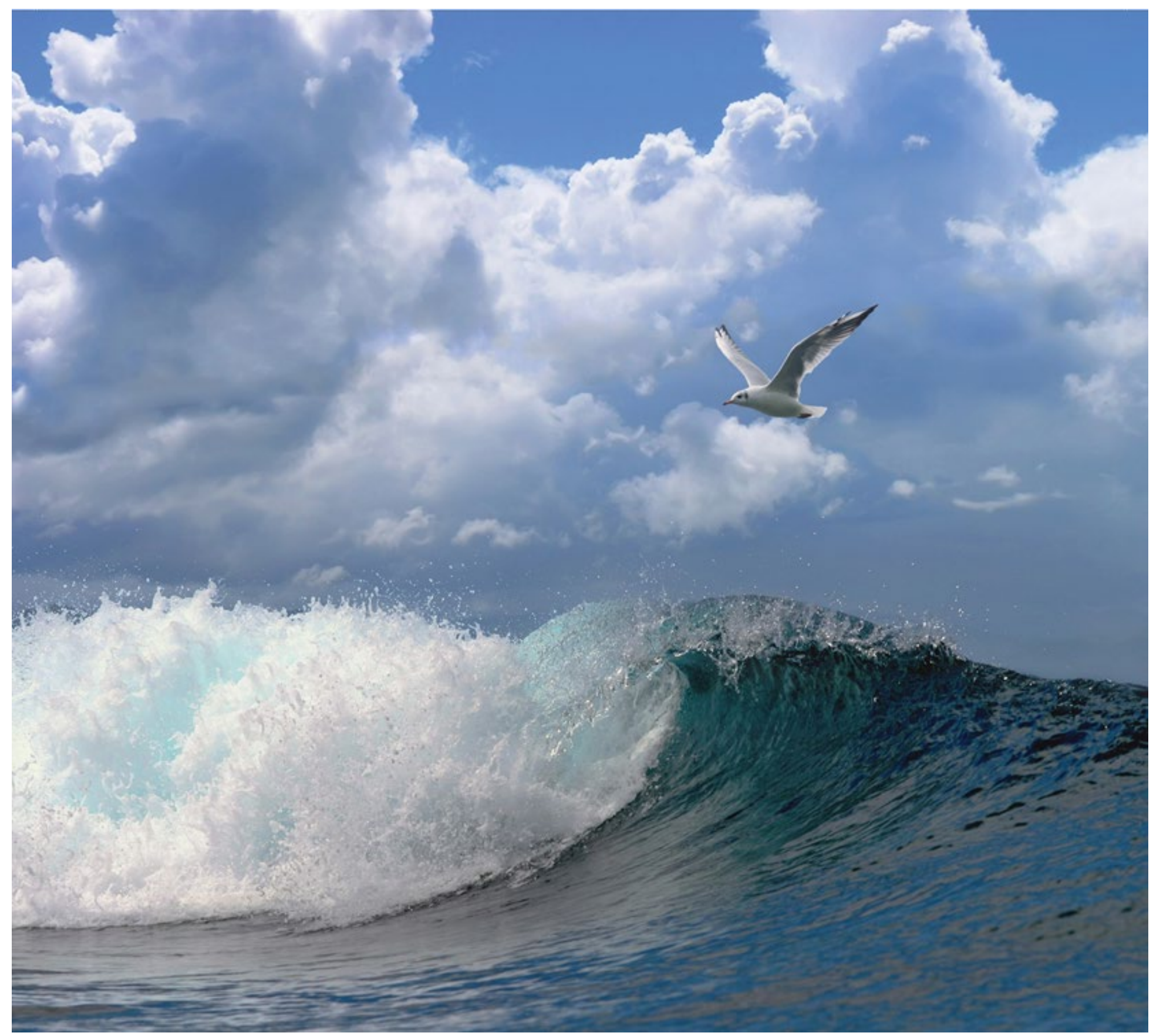

\title{
Starry ray in the ottertrawl and flyshoot fishery
}




\section{Starry ray in the ottertrawl and flyshoot fishery}

Author(s): $\quad$ H.M.J. van Overzee, J.J. Poos, J. Batsleer \& P. Molenaar

Publication date: $4^{\text {th }}$ of April 2019

Wageningen Marine Research

Den Helder, April 2019

CONFIDENTIAL: NO

Wageningen Marine Research report C033.19 
H.M.J. van Overzee, J.J. Poos, J. Batsleer \& P. Molenaar, 2019. Starry ray in the ottertrawl and flyshoot fishery. Wageningen, Wageningen Marine Research (University \& Research centre), Wageningen Marine Research report. 38 pp.

Keywords: Starry ray, ottertrawl fishery, flyshoot fishery

Client: $\quad$ Wouter van Broekhoven on behalf of CVO, Osprey Fish, and Ekofish Group Postbus 59

8320 AB Urk

This report can be downloaded for free from https://doi.org/10.18174/474383 Wageningen Marine Research provides no printed copies of reports

Wageningen Marine Research is ISO 9001:2015 certified.

(C) Wageningen Marine Research

\begin{abstract}
Wageningen Marine Research, an institute Wageningen Marine Research accepts no liability for consequential damage, nor within the legal entity Stichting for damage resulting from applications of the results of work or other data Wageningen Research (a foundation under obtained from Wageningen Marine Research. Client indemnifies Wageningen Dutch private law) represented by Dr. Marine Research from claims of third parties in connection with this application. M.C.Th. Scholten, Managing Director All rights reserved. No part of this publication may be reproduced and / or published, photocopied or used in any other way without the written permission KvK nr. 09098104, of the publisher or author.
\end{abstract}

WMR BTW nr. NL 8113.83.696.B16.

Code BIC/SWIFT address: RABONL2U

IBAN code: NL 73 RABO 0373599285 


\section{Contents}

$1 \quad$ Introduction

1.1 Aim of the project

$2 \quad$ Materials and Methods

2.1 Starry ray population size $\quad 7$

$\begin{array}{lll}2.1 .1 & \text { Survey data } & 7\end{array}$

2.1.2 Population model $\quad 8$

2.2 Starry ray catches $\quad 9$

2.2.1 Discards data 9

2.2.2 Raising procedure discards data $\quad 10$

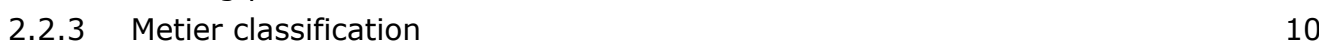

2.2.4 Catch model 11

2.2.5 Total starry ray catch of three MSC client fisheries fishery 11

$\begin{array}{lll}2.3 & \text { Proxy for starry ray mortality rate } & 11\end{array}$

$3 \quad$ Results $r 12$

3.1 Starry ray population size $\quad 12$

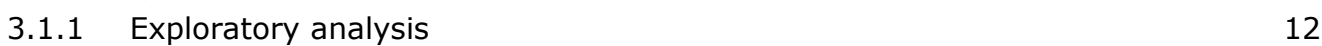

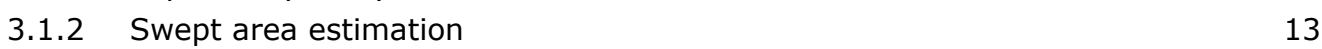

$\begin{array}{ll}3.1 .3 & \text { Depth estimation }\end{array}$

3.1.4 Population model 16

3.2 Starry ray catches $\quad 19$

3.2.1 Exploratory analysis $\quad 19$

3.2.2 Catch model $\quad 22$

3.2.3 Total starry ray catch of the three MSC client fisheries $\quad 22$

$\begin{array}{lll}3.3 & \text { Proxy for starry ray mortality rate } & 26\end{array}$

$\begin{array}{lll}\text { 3.3.1 Literature scan } & 26\end{array}$

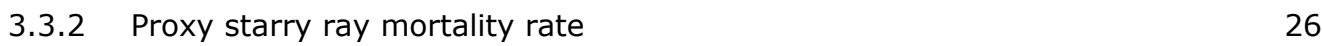

$\begin{array}{llr}4 & \text { Conclusions } & 28\end{array}$

$5 \quad$ Recommendations $\quad 30$

6 Quality Assurance $\quad 31$

$\begin{array}{ll}\text { Appendix I } & 32\end{array}$

$\begin{array}{lr}\text { Appendix II } & 33\end{array}$

$\begin{array}{lr}\text { References } & 36\end{array}$

$\begin{array}{lr}\text { Justification } & \mathbf{3 7}\end{array}$ 


\section{Summary}

Starry ray (Amblyraja radiata) is a widespread species in the central and Northern North Sea. It is a common unwanted bycatch species in the bottom trawl fishery and therefore almost exclusively discarded. Survey indices show that the starry ray population increased from the late seventies to the early eighties, followed by a decline in the early nineties. The declining trend in the survey indices since the early 1990s has resulted in the International Council for Exploration of the Sea (ICES) currently (i.e. 2016 to 2019) advising that "there should be no target fishery for starry ray and measures should be taken to reduce bycatch" (ICES, 2015).

The Dutch MSC certified ottertrawl (i.e. twinrig and outrig) and flyshoot fishery (Coöperative Visserij Organisatie, Osprey and Ekofish) targeting plaice and sole received MSC conditions concerning the impact of these fisheries on the starry ray population. As an overlap is visible in the spatial distribution of the certified fishery and starry ray and the survey indices show a declining trend, the effect of this fishery on the starry ray population needed to be evaluated. The aim of this study is to provide a tool that can be used to estimate the impact of the three MSC client fisheries on the starry ray population. Where the impact is defined as the \% of removal from the starry ray population. In order to estimate such impact, information is needed on (i) starry ray population size, (ii) total catches of three MSC client fisheries, and (iii) the survival rate of the discarded starry ray.

Based on the data collected within the International Bottom Trawl Survey (IBTS) and the Beam Trawl Survey (BTS) the starry ray population size was estimated. The presented results concern a minimum estimate of the starry population size as the model assumes a catchability of 1 , i.e. we assume all fish encountered by the gear were caught.

The annual starry ray catch rate (expressed in in $\mathrm{kg} /$ day and $\mathrm{kg} / \mathrm{kg}$ plaice landed) of the Dutch bottom-trawl and seine fishery was predicted by year and metier based on the data collected within the Dutch demersal discard programme in the period 2009-2017. Though this programme monitors discards, it is known that starry ray is almost exclusively discarded. It is therefore assumed that the monitored starry ray discards equals starry ray catch. Consequently the model predictions refer to starry ray catch rate rather than starry ray discards rate. The predicted catch rate can be extrapolated to the three MSC client fisheries. The preferred method would be to use the relationship between the predicted catch rate (expressed in $\mathrm{kg} /$ day) and effort (expressed in days at sea) of the three MSC client fisheries by year and metier to estimate the total starry ray catch of the three MSC client fisheries. However, the commissioning party noted that it is difficult to supply the exact effort information of the three MSC client fisheries. An alternative method was therefore also needed. As the three MSC client fisheries targets plaice the proposed alternative method was to use the relationship between the predicted catch rate (expressed in $\mathrm{kg} / \mathrm{kg}$ plaice landed) and plaice landings of the three MSC client fisheries by year and metier in order to estimate the total starry ray catch of the three MSC client fisheries.

A literature scan was performed in order to determine a proxy for the starry ray mortality rate. As the ottertrawl and flyshoot fishery have different characteristics, separate proxies for starry ray mortality rate were proposed for the two fisheries. Note that as there is no data to support this mortality rate, the proposed proxies should be used with extreme caution. The proxy of the starry ray mortality rate can be applied to the total catch estimate and compared with the calculated population size in order to estimate the impact (expressed in \% removal of estimated population size), of the three MSC client fisheries on the starry ray population. 
Starry ray (Amblyraja radiata) is a widespread species in the central and Northern North Sea. It is a common unwanted bycatch species in the bottom trawl fishery and therefore almost exclusively discarded. However, as the amount of discards has not been quantified and discard survival is unknown, fishing pressure on the stock is unknown (ICES, 2015).

Survey indices show that the starry ray population increased from the late seventies to the early eighties, followed by a decline in the early nineties. The reasons for this decline are unknown, but could include changes in environmental conditions, multi-species interactions (including with other skates and rays), fishing impacts, or even improved species identification (ICES, 2018). The declining trend in the survey indices since the early 1990s has resulted in the International Council for Exploration of the Sea (ICES) currently (i.e. 2016 to 2019) advising that "there should be no target fishery for starry ray and measures should be taken to reduce bycatch" (ICES, 2015).

The Dutch MSC certified twinrig, outrig and flyshoot fishery (Coöperatieve Visserij Organisatie, Osprey and Ekofish) targeting plaice and sole received conditions concerning the fishing impact on starry ray population as part of their Marine Stewardship Council (MSC) certification. As an overlap is visible in the spatial distribution of the certified fisheries and starry ray and the survey indices show a declining trend, the effect of the fisheries on starry ray, which is defined as an Endangered, Threatened or Protected (ETP) species by the MSC, needs to be evaluated.

\subsection{Aim of the project}

The aim of the project is to provide a tool that can be used to estimate the impact of the three MSC client fisheries on the starry ray population. Where the impact is defined as the \% of removal from the starry ray population. In order to evaluate the impact of the fisheries on the starry ray population, the following information is needed:

1. What is the starry ray population size?

2. What are the starry ray catches of the Dutch bottom-trawl and seine fishery?

3. What are the starry ray catches of the three MSC client fisheries?

4. What is the impact of the three MSC client fisheries on the starry ray population?

This project addresses questions 1 and 2 and provides a tool that can be used to address questions 3 and 4. 


\section{$2 \quad$ Materials and Methods}

\section{$2.1 \quad$ Starry ray population size}

The minimum starry ray population size has been estimated based on data collected within the International Bottom Trawl Survey (IBTS) and the Beam Trawl Survey (BTS) using the statistical package Intergrated Nested Laplace Approximation (INLA). This package has the advantage that it can combine, amongst others, spatial and temporal models into one. The model estimates the annual numbers of starry ray, taking account of haul location, year and depth. The presented results concern a minimum estimate of the starry population size as the model assumes a catchability of 1 , i.e. we assume all fish encountered by the gear are caught.

\subsubsection{Survey data}

The IBTS is an internationally coordinated survey, held in quarter 1 and quarter 3 of each year. The quarter 1 survey started in 1966, while the quarter 3 survey started in 1991 . Several countries contributed to the sampling effort, and over the years the survey methodology and survey gears have been standardized. The gear used in the survey is a "GOV" otter trawl, where a net is towed over the sea floor, held open by otter boards. In general, tows in the IBTS last 30 minutes, but shorter or longer tows have also been made.

The BTS is a survey conducted by several countries, held in quarter 3 of each year. The Dutch and German contribution to the survey consists of hauls by two vessels that cover a partly-overlapping survey area. The gear used onboard each of the vessels is a beam trawl, where the net is held open by a horizontal 8 metre steel beam. The survey started in 1987 on board of RV ISIS, covering mainly the southeastern part of the North Sea. In 1996 the second Dutch vessel, RV Tridens, started covering the central North Sea. In 2002, the German BTS started, first on board of RV Solea.

Trawl survey data for all relevant surveys in the North Sea are stored at ICES in the Database of Trawl Surveys (DATRAS). Haul-by-haul data from the surveys was downloaded from DATRAS. This haul-byhaul data contains catch per unit time by length, and the duration of each haul. Total lengths of the specimens have been measured to the centimetre below, and stored in $\mathrm{mm}$. From this information counts per haul by $\mathrm{cm}$ length class have been computed.

\subsubsection{Swept area estimation}

All hauls in the IBTS and BTS surveys have the haul duration stored with the count data. In addition, surface area covered by the trawls is stored for many hauls in the BTS. For the IBTS, the surface area is not stored, but several attributes of the gear opening and the distance covered by the survey for many hauls are available. From these a surface area has been calculated. For hauls where surface information was missing, surface information was estimated using predictions from a linear regression model of surface as a function of haul duration.

\subsubsection{Depth estimation}

In addition to the haul information, depth is also measured and stored for many hauls in the surveys. This depth information can be used to infer abiotic habitat association for our species. For hauls where depth information was missing, it was estimated using predictions from a Generalized Additive Model (GAM) of depth as a smooth function of latitude and longitude. The smooth function was a tensor spline using a maximum of 17 knots for the bases. The final smoothness is estimated by the GAM (Wood, 2006). In the GAM model a normal error distribution was assumed. 


\subsubsection{Population model}

The counts in each haul were modeled as a function of year, surface area, survey, and depth, with a spatial, or spato-temporal correlation structure using INLA (Rue et al. 2009). The spatial correlation is described using the Matern correlation function. The kappa parameter of the Matern correlation is estimated using a Gaussian Markovian Random Field. For this, an irregular grid, or mesh, is needed. This mesh was generated using INLA, and bounded by a non-convex hull around the coordinates of the data (Figure 1). The largest allowed triangle edge length within the mesh was $40 \mathrm{~km}$.

The effect of depth was modeled as a random walk model of order 2.

Model selection was done based on Watanabe-Akaike Information Criterion (WAIC). Once the final model was selected, 1000 samples were taken from the approximated posterior of that model. Those samples were then used to make forecasts that were projected on a 1 by $1 \mathrm{~km}$ grid. The projection grid was bounded by the original mesh of the INLA analysis, and the sum of counts per $\mathrm{km}^{2}$ for the each year over the entire grid results in an estimate of the total population size. The credible intervals are estimated from the 0.025 and 0.975 quantiles of the population sizes estimated from the posterior samples.

The output of the model is a population estimate by year in number. Thereafter numbers needed to converted to weight. For this a yearly average weight of starry ray was calculated by first calculating the weight for all observations using a length-weight relationship described by Bedford et al. (1986):

$w=\alpha L^{\beta}$

Equation 1

, where $w$ is the weight of a specimen in grams, $L$ is the length of a specimen in centimetres, $\alpha$ $=0.15665$ and $\beta=2.190$. Thereafter the yearly average weight per year was calculated as:

weight $_{\text {year }}=\frac{\sum_{\text {haul }} w_{\text {year }, \text { haul }} \times n r_{\text {year, haul }}}{\text { total } n r_{\text {year }}}$

Equation 2

, where $\mathrm{w}_{\text {year,haul }}$ is total weight per year and haul which is calculated with Equation $1, \mathrm{nr}_{\text {year, haul }}$ is total number observed per year and haul, total $\mathrm{nr}_{\text {year }}$ is total number observed per year. Then the total population biomass was calculated by multiplying the yearly average weight with the yearly model estimates of starry ray population numbers.

\section{Constrained refined Delaunay triangulation}

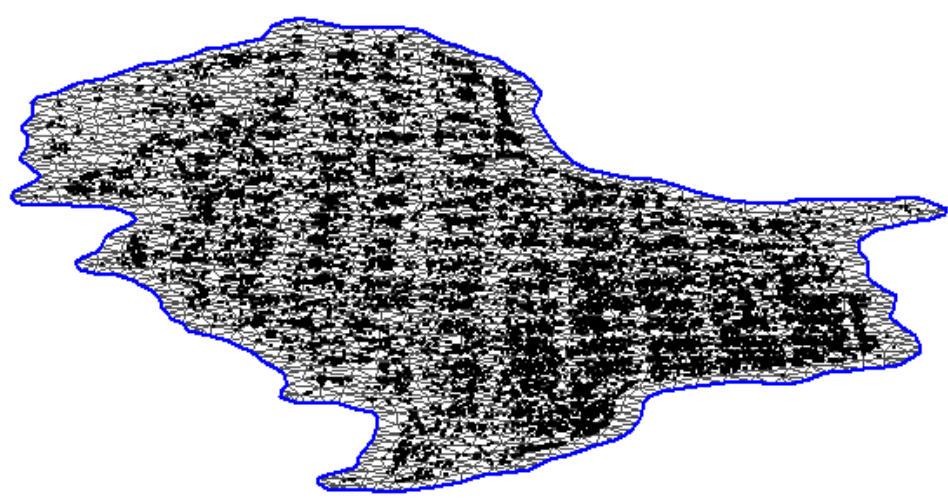

Figure 1. Mesh used for INLA model, black dots indicate tows included in analysis. 


\subsection{Starry ray catches}

Under the assumption that starry ray is exclusively discarded (ICES, 2015), starry ray catches of the Dutch demersal fleet have been estimated based on the data collected within the Dutch demersal discard programme in the period 2009-2017, where a distinction is made between data collected within the observer programme and data collected within the self-sampling programme.

\subsubsection{Discards data}

The collection of discards data has been enforced through the Data Collection Regulation (DCR) and subsequently the Data Collection Framework (DCF) of the European Commission (EC). To comply with this ruling, 6-18 active demersal fishing trips have been monitored annually since 2000 in the Netherlands by scientifically-trained observers (i.e. observer programme). In 2009, revisions to the DCF required member states to increase sampling intensity to i) improve the precision of their estimates and ii) the number of sampled fishing fleets (metiers). In foresight of the expenses involved, an affordable self-sampling programme commenced in the Netherlands for the Dutch demersal fisheries in the North Sea in 2009 (see Box 1 for further information on the sampling programmes).

The collected discards data is used, amongst others, by the ICES working groups for the assessment for stocks in the North Sea. Discard data collected within the observer programme have been used by the ICES working groups up to and including 2010.

\section{Box 1: Discards sampling of the Dutch demersal fleet Self-sampling programme}

The sampling plan of the self-sampling programme is based on a demersal reference fleet consisting of 2025 vessels with protocol-instructed fishers that collect discard samples according to a predefined schedule during their regular commercial operations. Within a trip operational- and catch data are collected by the crew each time the fishing gear is deployed. Furthermore, the crew is instructed to retain a sample (ca. 80 $\mathrm{kg}$ ) of the discards which is representative for the sampled haul during two separate hauls. The samples are collected in large plastic bags which are sealed off, labelled and cool-stored until the vessel returns to the port. Back at port, the discard samples are collected by WMR staff and returned to the laboratory for analysis. From each sample all species are identified. Numbers at length are recorded for all fish species, Norway lobster and edible crab. Numbers without length measurements are recorded for all remaining (benthos) species. Standard data management software is used to enter and subsequently audit all data before the data is stored in the centralised WMR database. Hauls sampled during the self-sampling trips are verified using the observer data from the same haul from observer trips (Verkempynck et al., in prep). In addition, the observer trips have proven to be of importance for training crew members in sampling of discards. Also, the observer trips are appreciated by the skipper and the members of the reference fleet, it bridges the gap between scientists and crew.

\section{Observer programme}

The selection of the observer trips occurred in cooperation with the active demersal fleet up to 2011. From 2011 onwards, observers went onboard trips where self-sampling was also conducted. Within a trip, operational- and catch data are collected by the observer each time the fishing gear is deployed. Furthermore $>60 \%$ of the hauls is sampled by one or two observers in each trip. For each sampled haul, the total volume of the catch is estimated and a sample (ca. $40 \mathrm{~kg}$ ) of the discards which is representative for the sampled haul is collected. From each sample all species are identified, numbers at length are recorded for all fish species, Norway lobster and edible crab and numbers without length measurements are recorded for all remaining (benthos) species. Standard data management software is used to enter and subsequently audit all data before the data is stored in the centralised WMR database. 


\subsubsection{Raising procedure discards data}

A schematic overview of the raising procedure for the discards data is shown in Figure 2.

\subsubsection{Raising the samples to haul level}

Numbers (at length) have been registered for all individuals (by species) for each sample. Whenever a species is very abundant within the sample, a sub-sample of this species has been counted. The numbers (at length) have been multiplied with the sub-sample fraction to estimate total numbers (at length) within the sample (Figure 2; Step A). The numbers (at length) in the samples have been multiplied with the volume ratio between discard sample and total discards to estimate total numbers (at length) within that haul (Figure 2; Step B). Thereafter, the length/weight-relationship for starry ray described by Bedford et al. (1986) has been applied to convert numbers at length to weight at length.

\subsubsection{Raising sampled hauls to trip level}

Both numbers and weights for the sampled hauls are summed up. These numbers and weights have then been standardized into discards per unit effort (expressed in number/hour and $\mathrm{kg} / \mathrm{hour}$ ) rates by dividing them by the deployment duration (i.e. fishing time). Total numbers and weights per fishing trip have been calculated by multiplying the standardize rates with the duration of all hauls (Figure 2; Step C). Doing this we assume that the sampled hauls in a trip are representative in species composition and variance for all the other hauls in the same trip.

Effort (expressed in days at sea) and plaice landings per trip have been extracted from the WMR VISSTAT database containing the official Dutch logbook information. The total weights per fishing trip were then standardized into (i) starry ray discards per fishing day, and (ii) starry ray discards per kg plaice landed.

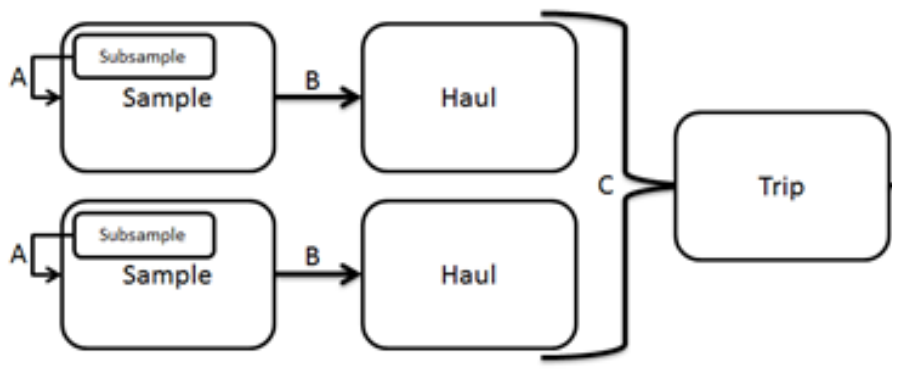

A: number in subsample $*$ subsample fraction

B: number in sample $* \frac{\text { Volume of (total catch of haul-total landings in haul) }}{\text { volume of discard sample }}$

C: sum of numbers in both samples $* \frac{\text { Total duration all hauls of thetrip }}{\text { Duration both sampled hauls }}$

Figure 2. Schematic overview of the raising process discards (taken from Verkempynck et al., 2018).

\subsubsection{Metier classification}

The WMR VISSTAT database was used to assign all sampled trips to their respective metier based on the level 6 for the metier classification defined by the European Union (EU) definitions (2008/969/EC Appendix IV) (See Appendix I Table I.1 for further information on the different metiers). 


\subsubsection{Catch model}

A negative binomial Generalised Linear Model (GLM) was used to relate the starry ray discards rate (expressed in $\mathrm{kg} / \mathrm{day}$ and $\mathrm{kg} / \mathrm{kg}$ plaice landed) collected in the sampling period 2009-2017 on trip level to sampling programme, year and metier. Sampling programme was included as an explanatory variable in the model because potential patchiness of the starry ray may be captured differently by the two programmes as the number of sampled hauls within a trip differs between the two programmes (see Box 1). Year was included as an explanatory variable in the model as it is expected that the discard rate may vary over years. Lastly, metier was included as an explanatory variable because the metiers can differ in their spatial distribution. For example, metier TBB_DEF_70-99_S300hp is mostly active in the southern North Sea and along the coast, while the majority of the effort of metier OTB_DEF_> 120 is concentrated at the Doggersbank and northeast of the Doggersbank (Verkempynck et al., 2018). One metier (SSC_DEF_70-99) for which no starry ray discards were observed throughout the sampling period has been excluded from the regression model. The Akaike's Information Criterion (AIC) was used to determine the optimal model fit.

\subsubsection{Total starry ray catch of three MSC client fisheries fishery}

The three MSC client fisheries in this report concerns three metiers of the otter trawl fisheries (i.e. OTB_DEF_70-90, OTB_DEF_100-119 and OTB_DEF_>120) and two metiers of the flyshoot fisheries (i.e.. SSC_DEF_100-119 and SSC_DEF_ > =120).

The starry ray discards data (expressed in $\mathrm{kg} / \mathrm{day}$ and $\mathrm{kg} / \mathrm{kg}$ plaice) predicted by the catch model (section 2.2.4) needed to be converted to the three MSC client fisheries. The preferred method would be:

a. Apply the relationship between starry ray catch rate and effort (expressed in days at sea) of the three MSC client fisheries by year and metier to estimate the total starry ray catch of the three MSC client fisheries.

However, the commissioning party noted that it is difficult to supply the exact effort information of the three MSC client fisheries. Therefore, as the three MSC client fisheries targets plaice the following alternative method was also proposed:

b. Apply the relationship between starry ray catch rate and plaice landings of the three MSC client fisheries by year and metier to estimate the total starry ray catch of the three MSC client fisheries.

\subsection{Proxy for starry ray mortality rate}

A literature scan was performed in order to determine a proxy for the starry ray mortality rate. 


\section{$3 \quad$ Results}

\subsection{Starry ray population size}

\subsubsection{Exploratory analysis}

In the IBTS, 23246 hauls were conducted since 1966. 16057 hauls were done in the first quarter IBTS, while 7189 hauls were done in the IBTS q3. Haul durations in the IBTS ranged between 5 and 90 minutes, with a mode of 30 minutes.

In the BTS 4078 hauls were conducted since 1987. Haul durations ranged between 5 and 60 minutes, with a median of 30 minutes. Surface estimates range between 0.0044 and $0.0858 \mathrm{~km} 2$, with approximately 206 hauls where surface was not recorded.

Lengths of the catches ranged between $10 \mathrm{~mm}$ and $>1000 \mathrm{~mm}$ (Figure 3). However, the majority of the observations were between lengths of $80-530 \mathrm{~mm}$. Lengths $>1000 \mathrm{~mm}$ were assumed to be incorrect observations (likely because of species misidentification with larger ray species in the North Sea), and removed from the data set.
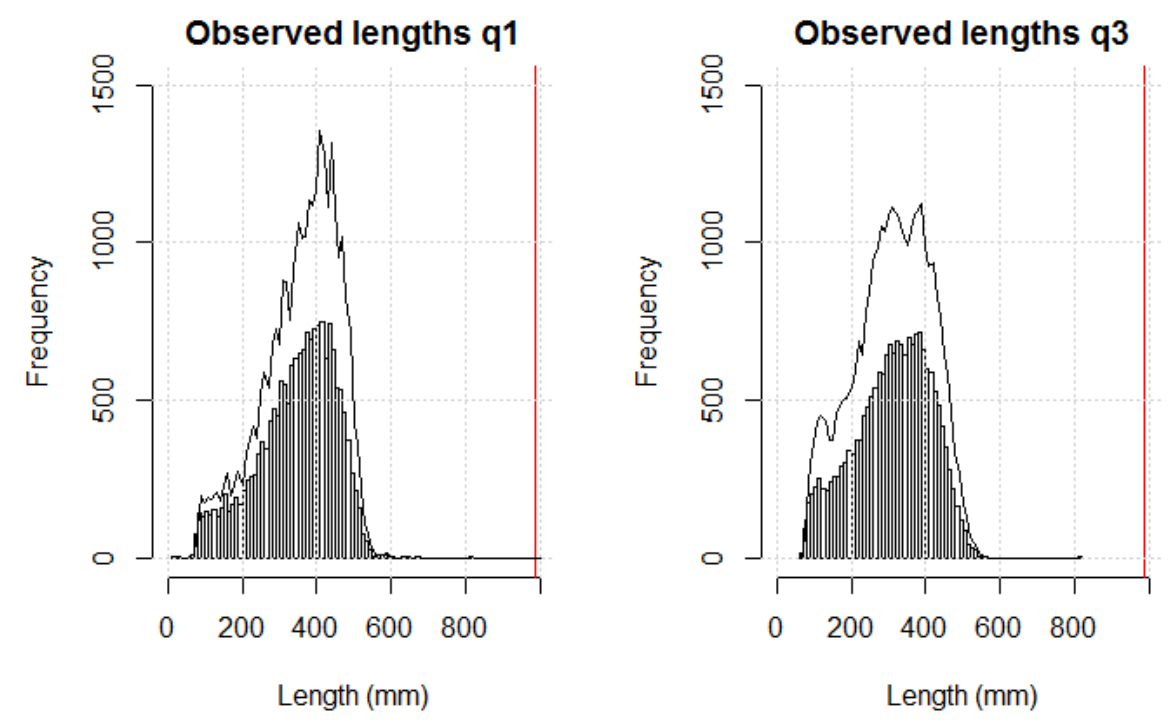

Figure 3. Histogram of observed lengths (bars) and total catches in numbers per length (drawn lines) for surveys in the two quarters. Vertical red line indicates cut-off point above which observations are assumed to be caused by species misidentification, or incorrect length measurements.

The geographical coverage of the North Sea was almost complete, apart from a lack of hauls in the Norwegian trench (Figure 4). The spatial distribution of starry ray in the hauls is heterogeneous, but present in all three surveys (Figure 4). 

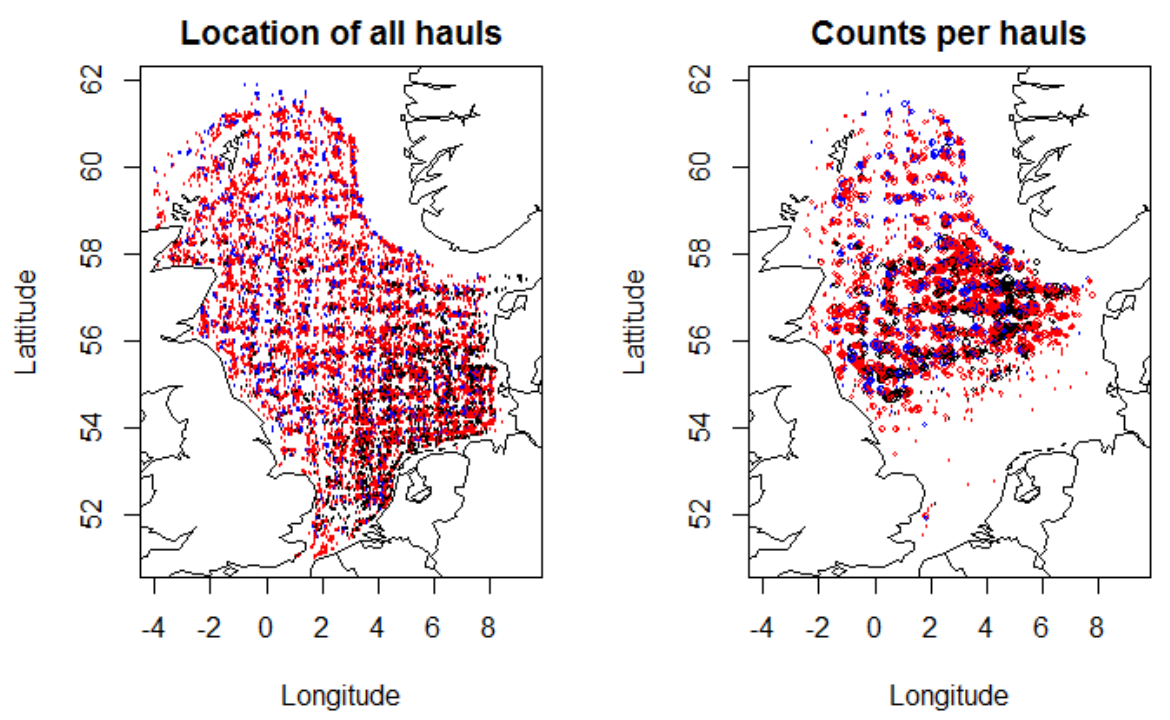

Figure 4. Spatial distribution of all hauls in the surveys (left panel), and geographic distribution of the catches in the surveys (right panel). The BTS hauls in black, IBTS quarter 1 hauls in red, and IBTS quarter 3 hauls in blue. In the right panel, the size of the bubble increases with increased counts.

The count data is dominated by hauls in which starry ray was absent, or present in very low numbers ( $<10$ individuals). Meanwhile, there were very few hauls with very large counts ( $>200$ individuals). This pattern was found in all three surveys (Figure 5).
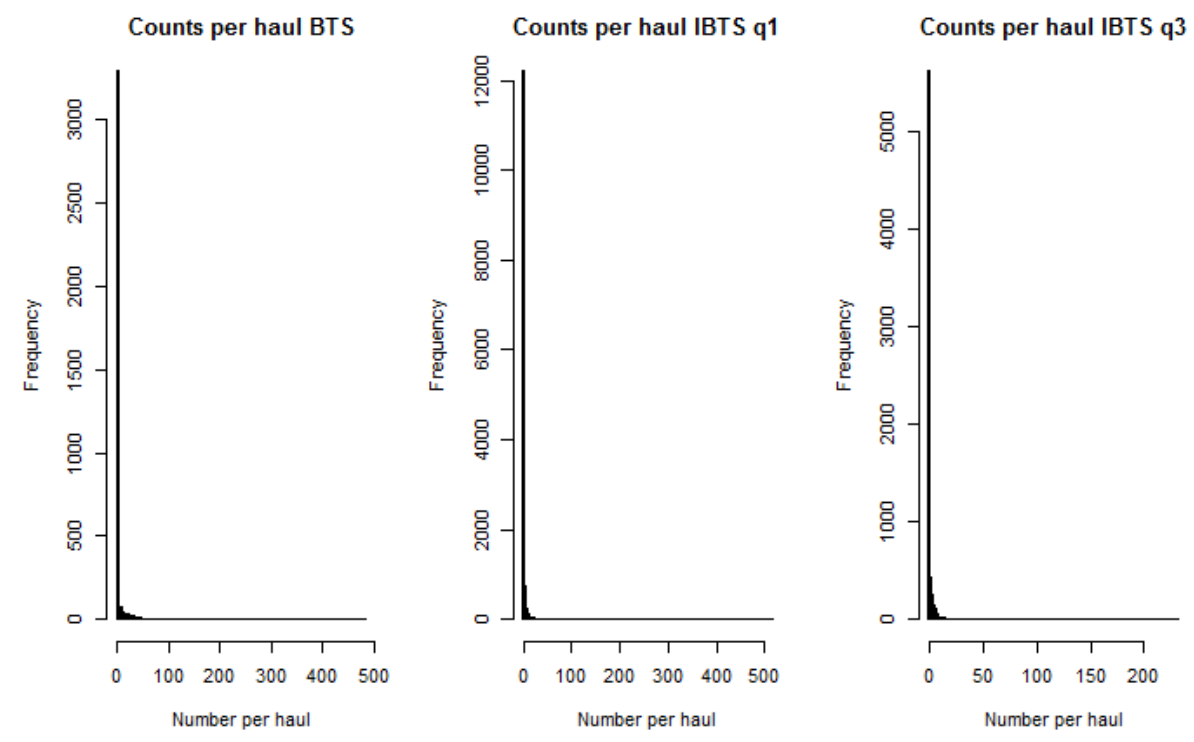

Figure 5. Histograms of count data in the three surveys.

\subsubsection{Swept area estimation}

\subsubsection{BTS}

For BTS, the count data included beam width and travelled distance. These were multiplied to generate a trawled surface for most of the hauls. For those hauls where travelled distance was missing, surface was estimated from haul duration, which was always recorded. Estimation of surface from haul duration was done by fitting a linear model where surface was the response variable and haul duration was the predictor. The model was fit without intercept, while assuming a normally distributed error. The model was significant $(\mathrm{df}=1,12741$; $\mathrm{p}$ value $<0.0001)$, and suggested a slope of $1.018 \mathrm{e}-3 \mathrm{~km} 2 / \mathrm{min}$ (Figure 6 ). The model explained $98.8 \%$ of the variance in the surface. The relationship between the surface and haul duration was then used to infer trawled surfaces for those 
hauls were surface was unknown. The median of the resulting estimates of trawl surface for all hauls was $0.030504 \mathrm{~km}^{2}$.

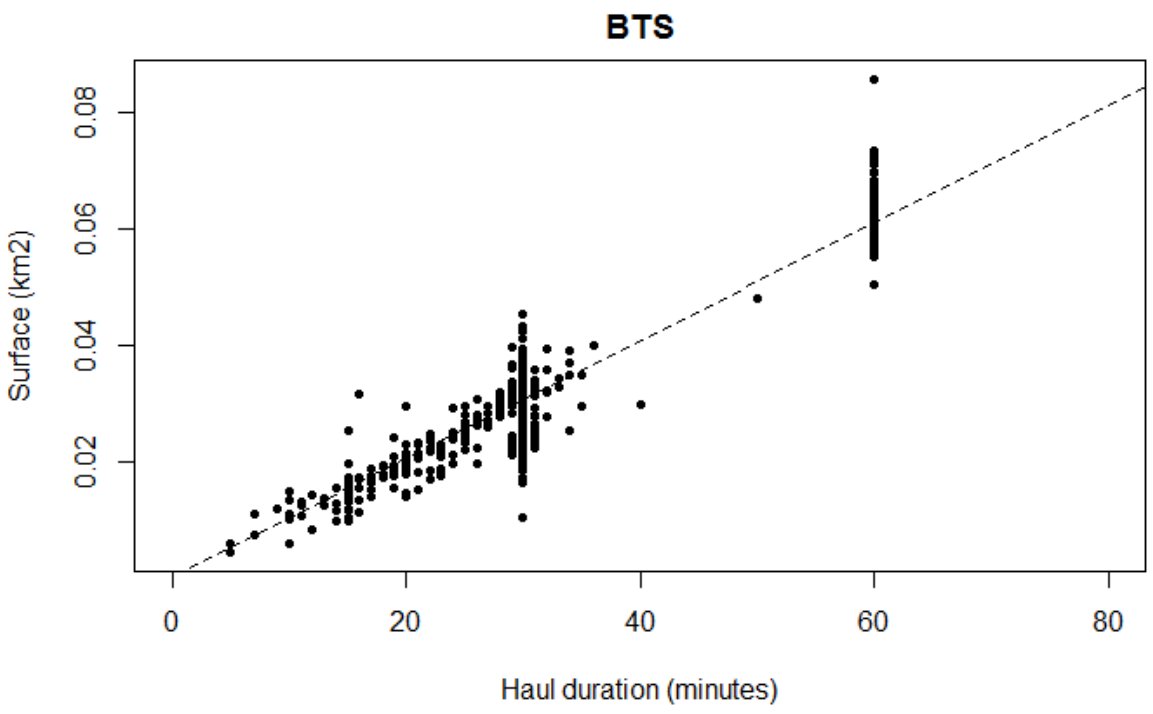

Figure 6. Scatterplot of surface versus haul duration for BTS. Dashed line indicates slope estimated by linear model regression without intercept.

\subsubsection{IBTS}

For IBTS, haul duration was recorded for all hauls and door spread and wingspread were recorded for a substantial number of hauls. These data were stored in a separate DATRAS dataset. These data were downloaded and merged to the count data. For calculating the surface we use the haul duration. Hauls with durations $>80$ minutes were removed from the data, assuming that these were invalid or not correctly recorded (Figure 7). The door spread measures the distance between the otter boards, while the wingspread measures the distance between the wing of the net in between the doors. By definition, the door spread should thus be larger than the wing spread, and this is indeed the case for all records (Figure 7).
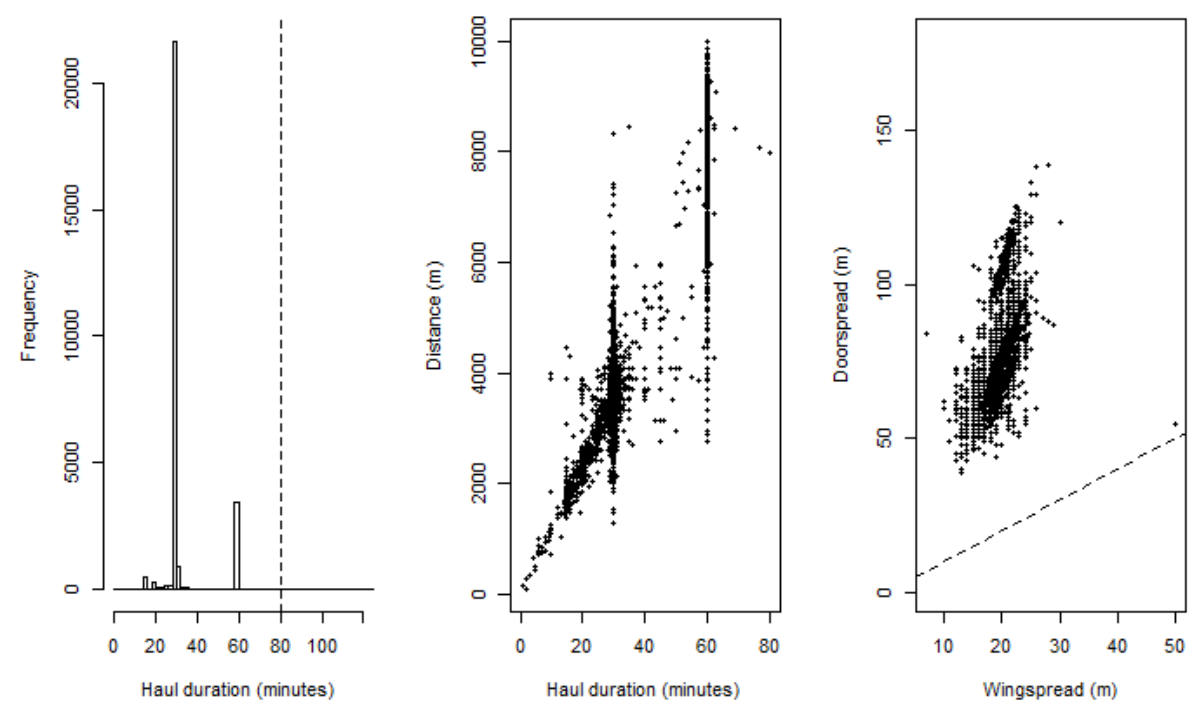

Figure 7. Histogram of IBTS haul duration (left panel), scatterplot of distance versus haul duration (middle panel), and scatterplot of door spread versus wingspread (right panel). In the left panel, the vertical dashed line indicates the cut-off haul duration. Hauls lasting longer than this cut-off point (here at 80 minutes) are assumed to be invalid, or incorrectly recorded. In the right panel the diagonal dashed lines indicates a 1:1 relationship.

Estimating the trawled surface was a two-step approach. First, surface is calculated as distance times wingspread for all hauls where both were available. Results were divided by 1 e6 to derive at surface 
areas measured in $\mathrm{km} 2$ rather than $\mathrm{m} 2$. Wing spread was used rather than door spread under the assumption that there is little herding effect of the area between the doors and the wings. Second, a linear model was fit where surface was the response variable, and haul duration was the predictor. The model was fit without intercept, while assuming a normally distributed error. The model was significant ( $d f=1,6494 ; p$ value $<0.0001$ ), and suggested a slope of $2.293 \mathrm{e}-3 \mathrm{~km} / \mathrm{min}$ (Figure 8 ). The model explained $97.9 \%$ of the variance in the surface. The relationship between the surface and haul duration was then used to infer trawled surfaces for those hauls were surface was unknown. The median trawl surface for the IBTS was $0.0688 \mathrm{~km}^{2}$.

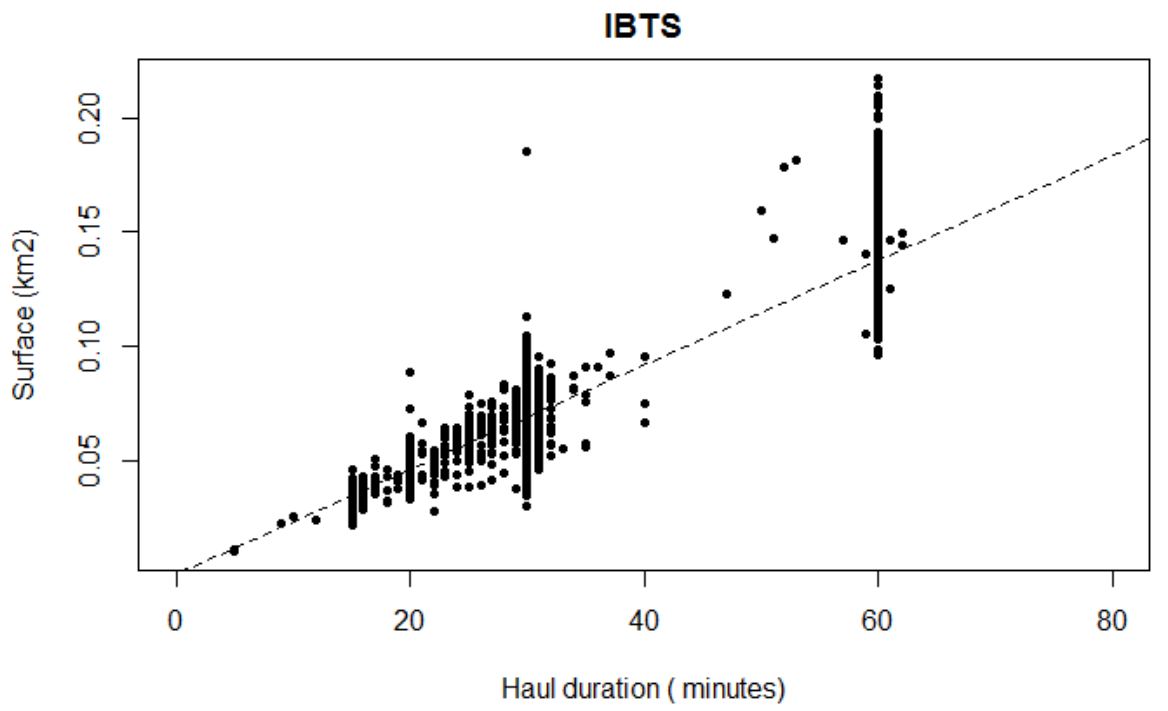

Figure 8. Scatterplot of surface versus haul duration for IBTS. Dashed line indicates slope estimated by linear model regression without intercept.

\subsubsection{Depth estimation}

Depth estimates were present for many but not all hauls in the dataset. The maximum fishing depth for IBTS standard stations in the North Sea is $200 \mathrm{~m}$. and in Division IIIa $250 \mathrm{~m}$. However, there are some hauls taken at depths deeper than $300 \mathrm{~m}$. Those hauls were removed from the data set. The remaining set had depth ranging between 6 and $294 \mathrm{~m}$, with a median of $58 \mathrm{~m}$. Given that the depth for a given location does not change much over the years, we use a generalized additive model to model a depth map, and to predict depths for those hauls where depth is missing (Figure 9). The GAM model with a $2 \mathrm{~d}$ smoother of latitude and longitude has a significant effect on depth ( $\mathrm{df}=262.0, \mathrm{~F}=$ $2375, \mathrm{p}<0.0001$ ) and explained $96.1 \%$ of the deviance (Figure 10 ).

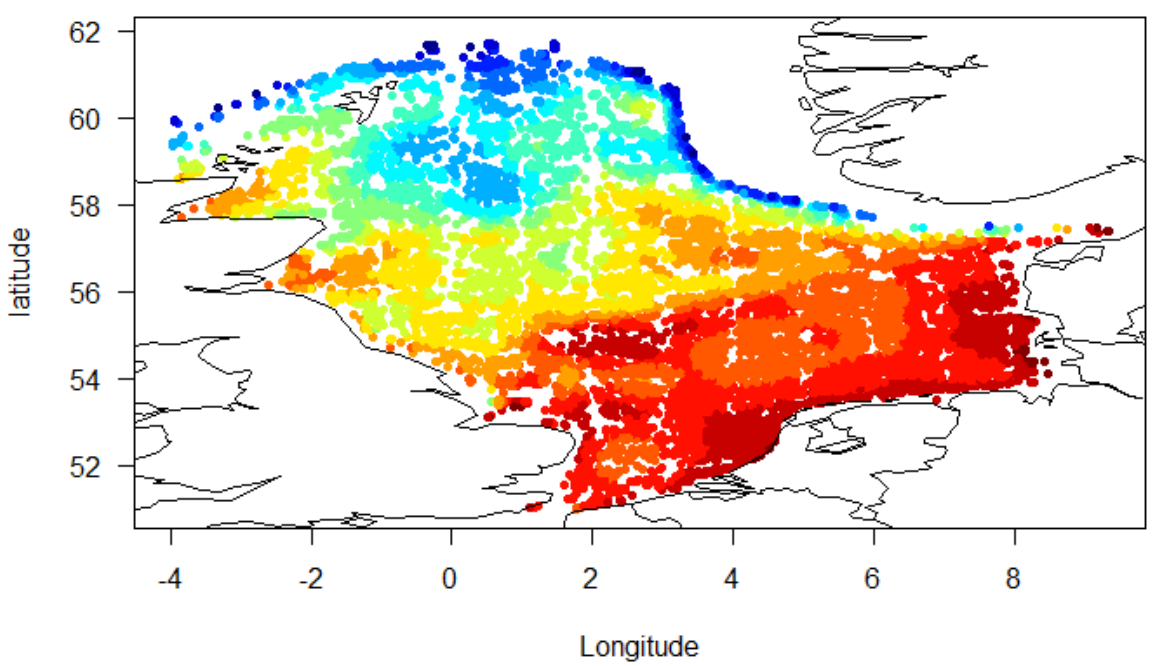

Figure 9. Model predicted depths. Cooler colours indicate deeper areas. 


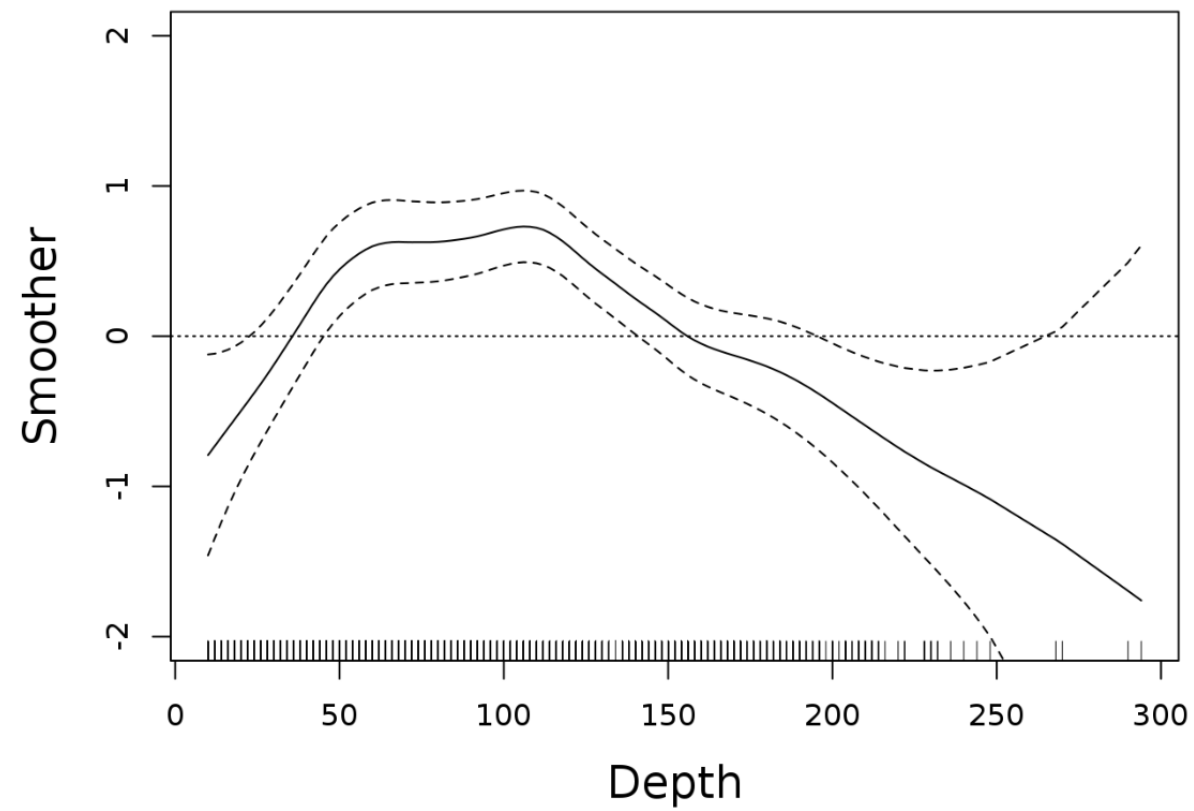

Figure 10. The GAM model with a $2 d$ smoother to estimate depth.

\subsubsection{Population model}

The results of the model selection and corresponding WAIC are shown in Table 1 . The final model is the spatio-temporal negative binomial model including depth. The fixed effects parameter estimates and the hyperparameter estimates of the selected model are shown in Appendix II (Tables II.1, II.2). The model estimates of the starry ray population is expressed in numbers (Appendix II; Figure II.1). In order to estimate the total stock weight the model estimates have been multiplied with the average annual weight of starry ray individual (Appendix II; Figure II.2).

The model shows an increase in the estimated total stock weight in the eighties, followed by a decline in halfway the nineties and onwards (Figure 10, Table 2). It must be noted that the presented results concern a minimum estimate of the starry population size as the model assumes a catchability of 1 .

Table 1. Model selection table. Model with the lowest WAIC in bold.

\begin{tabular}{l|l}
\hline Model name & WAIC \\
\hline Spatial Poisson model & 117756.0 \\
Spatial NB model & 57523.6 \\
Spatial NB model depth & 57505.3 \\
Spatial-temporal NB model depth & $\mathbf{5 5 7 4 9 . 8}$ \\
\hline
\end{tabular}




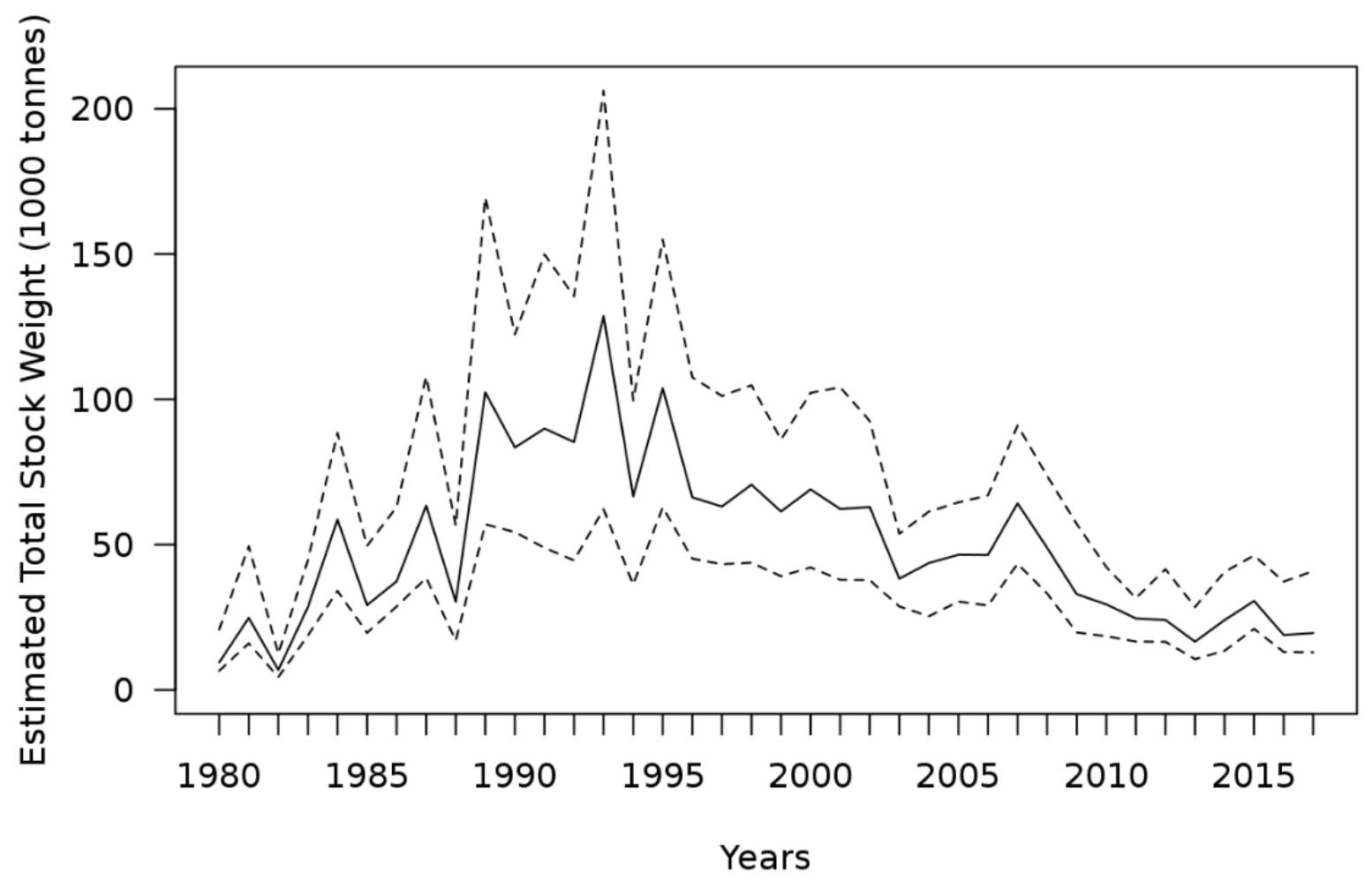

Figure 10. Estimated total starry ray stock weight (median - solid line) and corresponding uncertainty ( 0.025 quant and 0.975 quant - lower and upper dotted line) expressed in 1000 tonnes. 
Table 2. Estimated total stock weight (median) and corresponding uncertainty ( 0.025 quant and 0.975 quant) expressed in 1000 tonnes.

\begin{tabular}{|c|c|c|c|}
\hline & $0.025 q u a n t$ & median & 0.975 quant \\
\hline 1980 & 6.709 & 9.450 & 21.528 \\
\hline 1981 & 16.468 & 25.154 & 50.528 \\
\hline 1982 & 4.383 & 6.953 & 12.210 \\
\hline 1983 & 18.569 & 28.395 & 43.388 \\
\hline 1984 & 34.276 & 58.517 & 86.745 \\
\hline 1985 & 20.396 & 29.423 & 49.277 \\
\hline 1986 & 28.183 & 37.742 & 60.391 \\
\hline 1987 & 38.576 & 64.203 & 103.129 \\
\hline 1988 & 17.067 & 30.457 & 54.055 \\
\hline 1989 & 61.661 & 103.032 & 171.662 \\
\hline 1990 & 55.016 & 84.415 & 122.386 \\
\hline 1991 & 49.297 & 89.679 & 150.692 \\
\hline 1992 & 45.266 & 84.421 & 130.490 \\
\hline 1993 & 64.184 & 128.667 & 199.431 \\
\hline 1994 & 35.686 & 68.033 & 97.055 \\
\hline 1995 & 64.191 & 103.205 & 147.786 \\
\hline 1996 & 44.137 & 65.673 & 104.267 \\
\hline 1997 & 43.652 & 63.432 & 95.758 \\
\hline 1998 & 42.775 & 71.070 & 96.363 \\
\hline 1999 & 38.778 & 60.950 & 87.571 \\
\hline 2000 & 43.218 & 68.670 & 101.509 \\
\hline 2001 & 38.300 & 61.744 & 106.666 \\
\hline 2002 & 38.645 & 62.915 & 90.761 \\
\hline 2003 & 28.652 & 38.593 & 52.144 \\
\hline 2004 & 25.363 & 43.860 & 59.255 \\
\hline 2005 & 30.200 & 46.950 & 65.787 \\
\hline 2006 & 29.998 & 47.363 & 64.999 \\
\hline 2007 & 43.413 & 64.677 & 89.812 \\
\hline 2008 & 33.952 & 49.131 & 72.681 \\
\hline 2009 & 20.163 & 33.142 & 55.937 \\
\hline 2010 & 18.876 & 29.576 & 41.442 \\
\hline 2011 & 17.116 & 24.459 & 31.039 \\
\hline 2012 & 17.117 & 24.273 & 39.628 \\
\hline 2013 & 11.133 & 16.919 & 28.178 \\
\hline 2014 & 13.818 & 24.165 & 40.672 \\
\hline 2015 & 21.284 & 30.876 & 45.358 \\
\hline 2016 & 13.435 & 19.129 & 37.190 \\
\hline 2017 & 13.029 & 19.388 & 39.127 \\
\hline
\end{tabular}




\subsection{Starry ray catches}

\subsubsection{Exploratory analysis}

192 observer trips, covering six metiers, have been executed in the period 2000-2017 (Table 3). 6755 hauls were conducted of which 6623 hauls have been sampled. The majority of the observer trips took place onboard larger beam trawl vessels fishing with 70-99 mm mesh (metier TBB_DEF_7099_G300hp). Starry ray was observed within 234 hauls during 27 trips, covering 5 metiers.

1250 self-sampling trips, covering 13 metiers, have been executed in the period 2009-2017 (Table 3). 39465 hauls were conducted of which 2478 hauls have been sampled. TBB_DEF_70-99_G300hp was the most sampled metier (608 sampled trips in 2009-2017), followed by TBB_DEF_70-99_S300hp (167 sampled trips in 2009-2017). OTB_MCD_70-99 (147 sampled trips in 2009-2017), OTB_DEF_7099 (92 sampled trips in 2009-2017), and OTB_DEF_100-119 (85 sampled trips in 2009-2017). Starry ray was observed within 281 hauls during 188 trips, covering 11 metiers.

Lengths of the starry ray discards ranged between $70 \mathrm{~mm}$ and $620 \mathrm{~mm}$ (Figure 11). However, the majority of the observations were between lengths of $110-510 \mathrm{~mm}$.

The spatial distribution of starry ray observations shows a widespread distribution mainly in the central North Sea (Figure 12). The observations in the southern North Sea possibly concern misidentification (e.g. between starry ray and thornback ray (Raja clavata)).

Observer trips $\quad$ self.
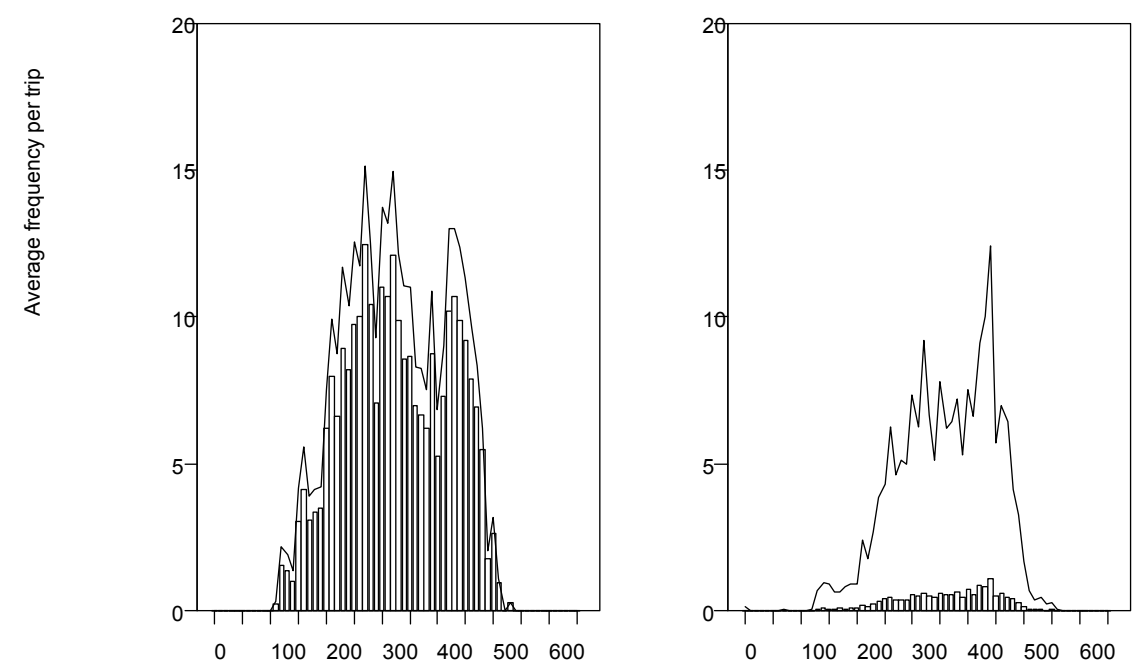

Lengte (mm)

Figure 11. Histogram of observed lengths (bars) and total discards in numbers per length (drawn lines) for the observer trips (left) and the self-sampling trips (right). 

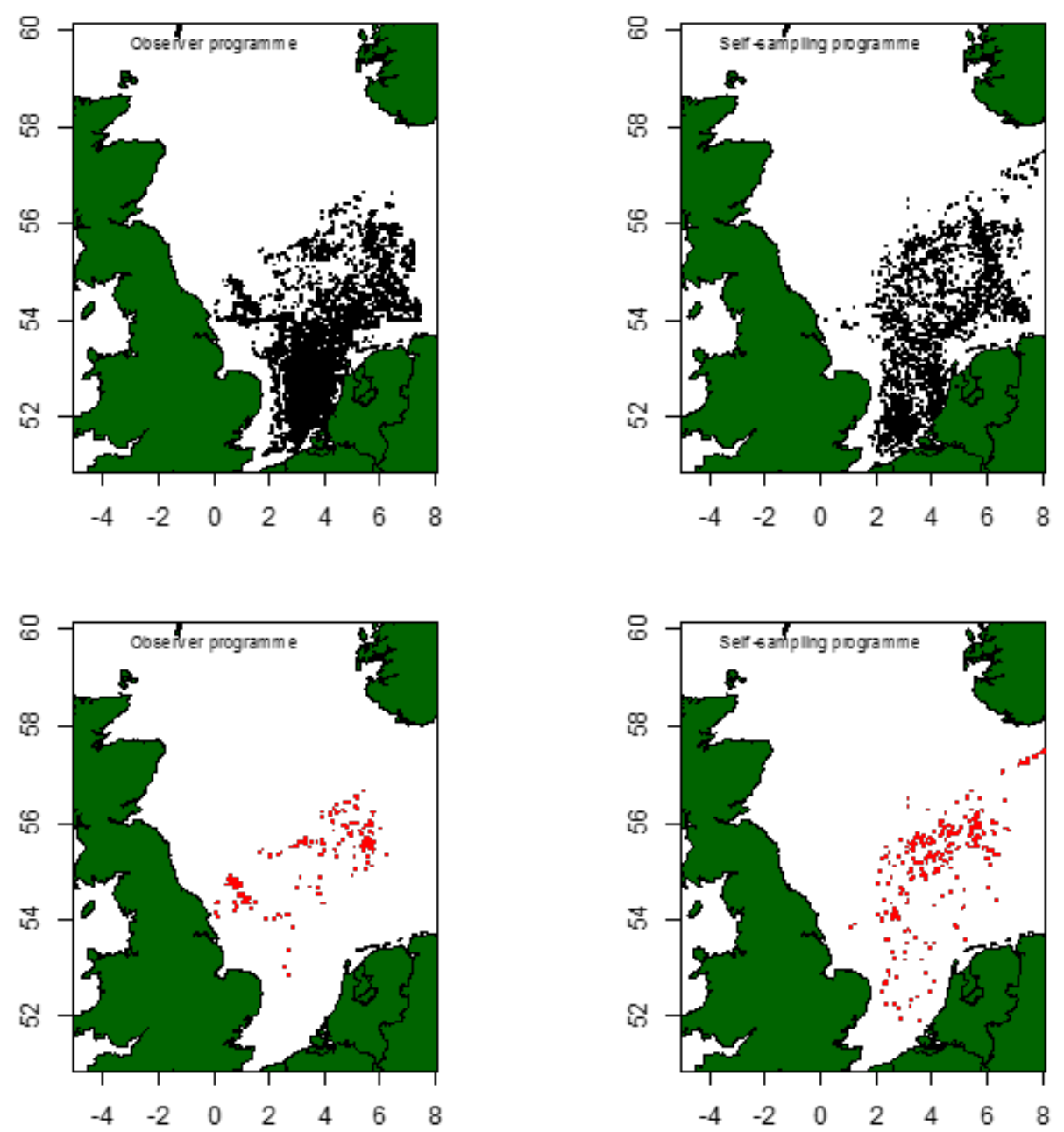

Figure 12. Spatial distribution of all sampled hauls (top panels) and hauls where starry ray was observed (lower panels) by sampling programme. 


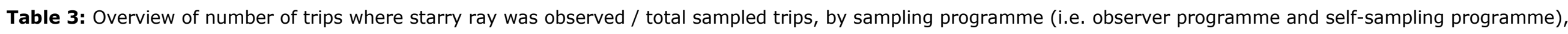
year and metier. See Appendix I (Table I.1) for further information on the different metiers

\begin{tabular}{|c|c|c|c|c|c|c|c|c|c|c|c|c|c|c|c|c|c|c|}
\hline & 2000 & 2001 & 2002 & 2003 & 2004 & 2005 & 2006 & 2007 & 2008 & 2009 & 2010 & 2011 & 2012 & 2013 & 2014 & 2015 & 2016 & 2017 \\
\hline \multicolumn{19}{|l|}{ Observer trips } \\
\hline OTB_DEF_100-119 & $0 / 3$ & $1 / 1$ & & $1 / 1$ & & & & & & & & & & $1 / 1$ & $2 / 2$ & $1 / 1$ & & \\
\hline OTB_DEF_70-99 & & & $0 / 1$ & $0 / 2$ & & & & $0 / 1$ & & $0 / 1$ & $1 / 2$ & & $1 / 1$ & $1 / 1$ & & & & \\
\hline OTB_MCD_70-99 & & & & & & & & $0 / 2$ & $2 / 3$ & $0 / 1$ & & & $1 / 2$ & $1 / 1$ & $0 / 2$ & & $0 / 1$ & $1 / 3$ \\
\hline TBB_DEF_100-119 & $0 / 1$ & & & & $1 / 1$ & $0 / 1$ & & & & & & & $1 / 1$ & & & & $0 / 1$ & $1 / 1$ \\
\hline TBB_DEF_70-99_G300hp & $1 / 12$ & $1 / 4$ & $1 / 6$ & $1 / 9$ & $0 / 8$ & $0 / 10$ & $0 / 13$ & $0 / 10$ & $1 / 10$ & $0 / 8$ & $2 / 8$ & $0 / 8$ & $0 / 4$ & $1 / 6$ & $0 / 4$ & $1 / 6$ & $1 / 6$ & $0 / 5$ \\
\hline TBB_DEF_70-99_S300hp & $0 / 2$ & $0 / 1$ & & & $0 / 1$ & & $0 / 1$ & & & & & & $0 / 2$ & $0 / 1$ & $0 / 2$ & $0 / 3$ & $0 / 1$ & $0 / 1$ \\
\hline \multicolumn{19}{|l|}{ Self-sampling trips } \\
\hline OTB_DEF_> =120 & & & & & & & & & & & & & $0 / 1$ & & $1 / 1$ & $0 / 3$ & $0 / 2$ & \\
\hline OTB_DEF_100-119 & & & & & & & & & & $2 / 4$ & $3 / 9$ & $2 / 10$ & $3 / 10$ & $7 / 13$ & $7 / 16$ & $7 / 13$ & $4 / 8$ & $1 / 2$ \\
\hline OTB_DEF_70-99 & & & & & & & & & & $0 / 2$ & $0 / 16$ & $0 / 10$ & $3 / 13$ & $3 / 8$ & $2 / 8$ & $7 / 20$ & $5 / 6$ & $4 / 11$ \\
\hline OTB_MCD_70-99 & & & & & & & & & & $1 / 6$ & $1 / 5$ & $1 / 16$ & $4 / 16$ & $2 / 19$ & $3 / 19$ & $2 / 17$ & $2 / 23$ & $3 / 27$ \\
\hline SSC_DEF_> $=120$ & & & & & & & & & & & & $0 / 2$ & $2 / 2$ & $5 / 5$ & $1 / 3$ & $1 / 4$ & $2 / 3$ & \\
\hline SSC_DEF_100-119 & & & & & & & & & & & & $0 / 2$ & $2 / 6$ & $1 / 2$ & $0 / 3$ & $0 / 4$ & $0 / 1$ & \\
\hline TBB_DEF_>=120 & & & & & & & & & & & & & & $2 / 2$ & & $2 / 3$ & & $0 / 1$ \\
\hline TBB_DEF_100-119 & & & & & & & & & & $2 / 7$ & 9/14 & $0 / 6$ & $6 / 15$ & $4 / 11$ & $5 / 9$ & $4 / 5$ & $8 / 9$ & $5 / 10$ \\
\hline TBB_DEF_70-99_G300hp & & & & & & & & & & $1 / 44$ & $5 / 68$ & $0 / 67$ & $4 / 63$ & $5 / 55$ & $9 / 80$ & $5 / 66$ & $4 / 80$ & $8 / 85$ \\
\hline TBB_DEF_70-99_S300hp & & & & & & & & & & $0 / 4$ & $0 / 21$ & $0 / 15$ & $0 / 17$ & $1 / 17$ & $0 / 20$ & $1 / 26$ & $1 / 24$ & $3 / 23$ \\
\hline Total & $1 / 18$ & $2 / 6$ & $1 / 7$ & $2 / 13$ & $1 / 10$ & $0 / 11$ & $0 / 14$ & $0 / 13$ & $3 / 13$ & $6 / 77$ & $21 / 143$ & $3 / 136$ & $27 / 153$ & $34 / 142$ & $30 / 169$ & $31 / 181$ & $27 / 167$ & $26 / 169$ \\
\hline
\end{tabular}




\subsubsection{Catch model}

The number of sampled trips for the larger mesh sized metiers is limiting (Table 3). As these metiers cover similar fishing grounds (Verkempynck et al. ,2018), it was decided to merge these metiers by gear:

- OTB_DEF_100-119 and OTB_DEF_> $=120$ into OTB_DEF_> $=100$

- SSC_DEF_100-119 and SSC_DEF_> 120 into SSC_DEF_> $>100$

- TBB_DEF_100-119 and TBB_DEF_> $=120$ into TBB_DEF_> $=100$.

The observed amount of discards (expressed in in $\mathrm{kg} / \mathrm{day}$ and $\mathrm{kg} / \mathrm{kg}$ plaice landed) within the two sampling programmes differed between metiers and years (Table 5). The highest rates were observed in the more northerly active metiers, namely OTB_DEF_> $=100$, SSC_DEF_> $=100$ and TBB_DEF_>=100.

The results of the negative binomial GLM selection and corresponding AIC are shown in Table 4. The Akaike's Information Criterion (AIC) is lowest when sampling programme is not included. The parameter estimates of the selected model are shown in Appendix II (Tables II.3-II.4).

The regression model predicts the starry ray discard rate (expressed in $\mathrm{kg} / \mathrm{day}$ and $\mathrm{kg} / \mathrm{kg}$ plaice landed) and corresponding uncertainty by year and metier (Tables 6-7). As it is assumed that starry ray is exclusively discarded (ICES, 2015), the model predictions refer to starry ray catch rate rather than starry ray discard rate.

Table 4. Model selection table for the negative binomial GLM selection with response variable discards (expressed in $\mathrm{kg} / \mathrm{day}$ and $\mathrm{kg} / \mathrm{kg}$ plaice landed). Model with the lowest AIC in bold.

\begin{tabular}{l|c|c}
\hline & AIC & AIC \\
Model name & Discards (kg/day) & Discards (kg/kg plaice landed) \\
\hline GLM NB model prog, year, metier & 3342.4 & 204.65 \\
GLM NB model year, metier & $\mathbf{3 3 4 0 . 6}$ & $\mathbf{2 0 2 . 8 1}$ \\
GLM NB model metier & 3363.5 & 204.23 \\
\hline
\end{tabular}

\subsubsection{Total starry ray catch of the three MSC client fisheries}

The total starry ray catch of the three MSC client fisheries can be calculated by year and metier using the relationship between the starry ray catch rate (see section 3.2.1) and effort or plaice information:

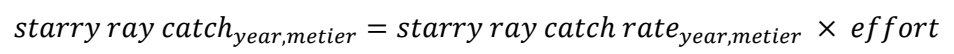
Equation 3

${\text { starry ray } \text { catch }_{\text {year,metier }}=\text { starry ray catch rate }}_{\text {year,metier }} \times$ plaice Equation 4

, where starry ray catch rate is expressed in $\mathrm{kg} / \mathrm{day}$ (Equation 3 ) or $\mathrm{kg} / \mathrm{kg}$ plaice landed (Equation 4), effort is expressed in total fishing days and plaice is expressed in total $\mathrm{kg}$ plaice landed. 


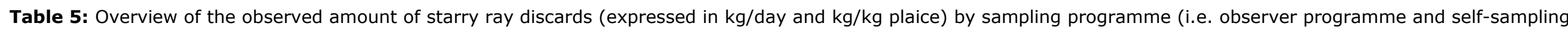
programme), year and metier. No values are available for metier SSC_DEF_70-99 as this metier was excluded from the regression model (see also section 2.2.4).

\begin{tabular}{|c|c|c|c|c|c|c|c|c|c|c|c|c|c|c|c|c|c|c|}
\hline & \multicolumn{9}{|c|}{ Starry ray discards (kg/day) } & \multicolumn{9}{|c|}{ Starry ray discards (kg/kg plaice landed) } \\
\hline & 2009 & 2010 & 2011 & 2012 & 2013 & 2014 & 2015 & 2016 & 2017 & 2009 & 2010 & 2011 & 2012 & 2013 & 2014 & 2015 & 2016 & 2017 \\
\hline \multicolumn{19}{|l|}{ Observer trips } \\
\hline OTB_DEF_>=100 & & & & & 2114.997 & 199.576 & 2.035 & & & & & & & 0.440 & 0.046 & 0.001 & & \\
\hline OTB_DEF_70-99 & 0.000 & 10.859 & & 36.160 & 12.087 & & & & & 0.000 & 0.017 & & 0.062 & 0.011 & & & & \\
\hline OTB_MCD_70-99 & 0.000 & & & 8.446 & 6.580 & 0.000 & & 0.000 & 1.133 & 0.000 & & & 0.027 & 0.031 & 0.000 & & 0.000 & 0.005 \\
\hline \multicolumn{19}{|l|}{ SSC_DEF_> $=100$} \\
\hline TBB_DEF_> $=100$ & & & & 1123.465 & & & & 0.000 & 50.913 & & & & 0.166 & & & & 0.000 & 0.013 \\
\hline TBB_DEF_70-99_G300hp & 0.000 & 1.590 & 0.000 & 0.000 & 7.252 & 0.000 & 2.557 & 0.303 & 0.000 & 0.000 & 0.002 & 0.000 & 0.000 & 0.003 & 0.000 & 0.006 & $<0.001$ & 0.000 \\
\hline TBB_DEF_70-99_S300hp & & & & 0.000 & 0.000 & 0.000 & 0.000 & 0.000 & 0.000 & & & & 0.000 & 0.000 & 0.000 & 0.000 & 0.000 & 0.000 \\
\hline \multicolumn{19}{|l|}{ Self-sampling trips } \\
\hline OTB_DEF_> =100 & 66.138 & 10.456 & 9.778 & 75.118 & 300.602 & 48.550 & 38.340 & 4.411 & 1.549 & 0.023 & 0.006 & 0.005 & 0.022 & 0.079 & 0.012 & 0.013 & 0.002 & 0.001 \\
\hline OTB_DEF_70-99 & 0.000 & 0.000 & 0.000 & 11.106 & 4.931 & 12.191 & 11.849 & 145.328 & 6.326 & 0.000 & 0.000 & 0.000 & 0.011 & 0.016 & 0.014 & 0.012 & 0.118 & 0.011 \\
\hline OTB_MCD_70-99 & 4.876 & 27.584 & 1.415 & 17.446 & 9.720 & 8.139 & 2.950 & 1.966 & 9.435 & 0.010 & 0.057 & 0.004 & 0.054 & 0.015 & 0.013 & 0.005 & 0.003 & 0.022 \\
\hline SSC_DEF_> =100 & & & 0.000 & 53.868 & 348.723 & 75.321 & 2.225 & 59.072 & & & & 0.000 & 1.148 & 1.187 & 0.079 & 0.003 & 0.316 & \\
\hline TBB_DEF_> = 100 & 2.526 & 127.566 & 0.000 & 13.437 & 40.488 & 47.854 & 173.301 & 78.603 & 18.912 & 0.001 & 0.032 & 0.000 & 0.002 & 0.082 & 0.010 & 0.032 & 0.019 & 0.005 \\
\hline TBB_DEF_70-99_G300hp & 0.405 & 2.685 & 0.000 & 2.035 & 4.497 & 12.862 & 7.413 & 15.854 & 3.931 & $<0.001$ & 0.002 & 0.000 & 0.001 & 0.003 & 0.004 & 0.003 & 0.004 & 0.003 \\
\hline TBB_DEF_70-99_S300hp & 0.000 & 0.000 & 0.000 & 0.000 & 0.109 & 0.000 & 0.700 & 0.284 & 3.960 & 0.000 & 0.000 & 0.000 & 0.000 & $<0.001$ & 0.000 & 0.001 & $<0.001$ & 0.019 \\
\hline
\end{tabular}


Table 6: Predicted starry ray catches (expressed in $\mathrm{kg} /$ day) by year and metier. No values are available for metier SSC_DEF_70-99 as this metier was excluded from the regression model (see also section 2.2.4).

\begin{tabular}{|c|c|c|c|c|c|c|c|c|}
\hline & & 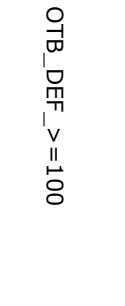 & 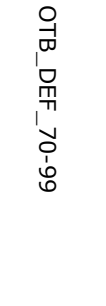 & 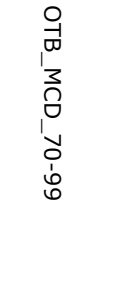 & 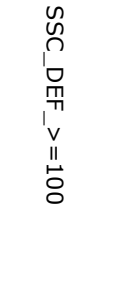 & 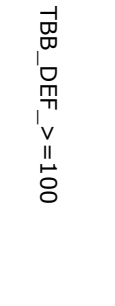 & 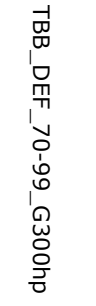 & 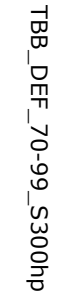 \\
\hline \multirow[t]{3}{*}{2009} & Prediction & 17.232 & 1.102 & 1.712 & 9.207 & 8.664 & 0.446 & 0.046 \\
\hline & Lower $95 \%$ ci & 3.384 & 0.215 & 0.389 & 1.074 & 1.753 & 0.127 & 0.010 \\
\hline & Upper $95 \%$ ci & 87.738 & 5.648 & 7.536 & 78.944 & 42.816 & 1.558 & 0.209 \\
\hline \multirow[t]{3}{*}{2010} & Prediction & 92.057 & 5.889 & 9.144 & 49.186 & 46.284 & 2.381 & 0.244 \\
\hline & Lower $95 \%$ ci & 23.373 & 1.587 & 2.649 & 6.886 & 12.109 & 0.939 & 0.074 \\
\hline & Upper $95 \%$ ci & 362.584 & 21.857 & 31.560 & 351.344 & 176.900 & 6.037 & 0.800 \\
\hline \multirow[t]{3}{*}{2011} & Prediction & 3.094 & 0.198 & 0.307 & 1.653 & 1.555 & 0.080 & 0.008 \\
\hline & Lower $95 \%$ ci & 0.720 & 0.046 & 0.083 & 0.226 & 0.350 & 0.027 & 0.002 \\
\hline & Upper $95 \%$ ci & 13.286 & 0.856 & 1.135 & 12.074 & 6.905 & 0.239 & 0.032 \\
\hline \multirow[t]{3}{*}{2012} & Prediction & 99.753 & 6.381 & 9.908 & 53.298 & 50.153 & 2.580 & 0.264 \\
\hline & Lower $95 \%$ ci & 26.140 & 1.708 & 3.097 & 8.248 & 13.509 & 1.034 & 0.082 \\
\hline & Upper $95 \%$ ci & 380.668 & 23.844 & 31.693 & 344.399 & 186.194 & 6.437 & 0.855 \\
\hline \multirow[t]{3}{*}{2013} & Prediction & 186.617 & 11.938 & 18.536 & 99.710 & 93.825 & 4.826 & 0.495 \\
\hline & Lower 95\% ci & 49.119 & 3.062 & 5.754 & 15.153 & 24.510 & 1.881 & 0.151 \\
\hline & Upper 95\% ci & 709.019 & 46.551 & 59.707 & 656.114 & 359.170 & 12.383 & 1.624 \\
\hline \multirow[t]{3}{*}{2014} & Prediction & 272.174 & 17.412 & 27.033 & 145.422 & 136.840 & 7.039 & 0.722 \\
\hline & Lower $95 \% \mathrm{ci}$ & 76.069 & 4.615 & 8.774 & 22.347 & 36.237 & 2.981 & 0.233 \\
\hline & Upper $95 \%$ ci & 973.827 & 65.684 & 83.289 & 946.344 & 516.744 & 16.623 & 2.236 \\
\hline \multirow[t]{3}{*}{2015} & Prediction & 198.198 & 12.679 & 19.686 & 105.897 & 99.647 & 5.126 & 0.525 \\
\hline & Lower $95 \%$ ci & 54.802 & 3.576 & 6.291 & 16.583 & 26.249 & 2.138 & 0.174 \\
\hline & Upper $95 \%$ ci & 716.798 & 44.954 & 61.601 & 676.236 & 378.283 & 12.289 & 1.590 \\
\hline \multirow[t]{3}{*}{2016} & Prediction & 411.212 & 26.306 & 40.843 & 219.711 & 206.744 & 10.635 & 1.090 \\
\hline & Lower $95 \%$ ci & 109.101 & 6.569 & 13.350 & 33.011 & 54.801 & 4.488 & 0.355 \\
\hline & Upper $95 \%$ ci & 1549.896 & 100.739 & 124.957 & 1462.315 & 779.976 & 25.199 & 3.351 \\
\hline \multirow[t]{3}{*}{2017} & Prediction & 298.193 & 19.076 & 29.618 & 159.324 & 149.922 & 7.712 & 0.790 \\
\hline & Lower $95 \% \mathrm{ci}$ & 76.059 & 5.119 & 9.916 & 23.079 & 40.230 & 3.278 & 0.256 \\
\hline & Upper $95 \%$ ci & 1169.083 & 71.089 & 88.462 & 1099.887 & 558.706 & 18.145 & 2.438 \\
\hline
\end{tabular}


Table 7: Predicted starry ray catches (expressed in $\mathrm{kg} / \mathrm{kg}$ plaice landed) by year and metier. No values are available for metier SSC_DEF_70-99 as this metier was excluded from the regression model (see also section 2.2.4).

\begin{tabular}{|c|c|c|c|c|c|c|c|c|}
\hline & & 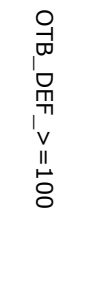 & 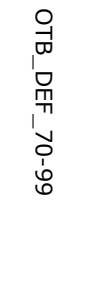 & 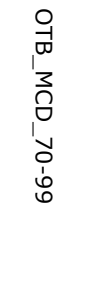 & 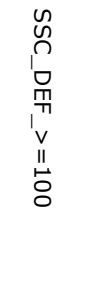 & 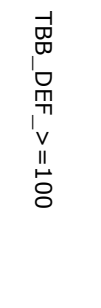 & 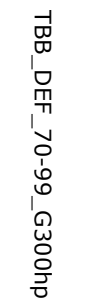 & 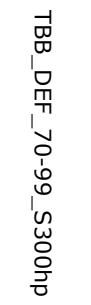 \\
\hline \multirow[t]{3}{*}{2009} & Prediction & 0.008 & 0.005 & 0.005 & 0.133 & 0.007 & 0.001 & 0.001 \\
\hline & Lower $95 \%$ ci & $<0.001$ & $<0.001$ & $<0.001$ & 0.001 & $<0.001$ & $<0.001$ & $<0.001$ \\
\hline & Upper $95 \%$ ci & 1.078 & 0.739 & 0.636 & 16.340 & 0.830 & 0.106 & 0.214 \\
\hline \multirow[t]{3}{*}{2010} & Prediction & 0.022 & 0.014 & 0.013 & 0.361 & 0.018 & 0.002 & 0.002 \\
\hline & Lower $95 \%$ ci & 0.002 & 0.001 & 0.001 & 0.039 & 0.002 & $<0.001$ & $<0.001$ \\
\hline & Upper 95\% ci & 0.230 & 0.149 & 0.148 & 3.299 & 0.176 & 0.025 & 0.071 \\
\hline \multirow[t]{3}{*}{2011} & Prediction & 0.001 & 0.001 & 0.001 & 0.018 & 0.001 & $<0.001$ & $<0.001$ \\
\hline & Lower $95 \%$ ci & $<0.001$ & $<0.001$ & $<0.001$ & $<0.001$ & $<0.001$ & $<0.001$ & $<0.001$ \\
\hline & Upper 95\% ci & 0.413 & 0.276 & 0.246 & 5.891 & 0.334 & 0.043 & 0.073 \\
\hline \multirow[t]{3}{*}{2012} & Prediction & 0.055 & 0.034 & 0.033 & 0.888 & 0.044 & 0.005 & 0.006 \\
\hline & Lower $95 \%$ ci & 0.013 & 0.006 & 0.008 & 0.385 & 0.010 & 0.001 & $<0.001$ \\
\hline & Upper $95 \%$ ci & 0.237 & 0.194 & 0.139 & 2.049 & 0.191 & 0.030 & 0.108 \\
\hline \multirow[t]{3}{*}{2013} & Prediction & 0.069 & 0.043 & 0.041 & 1.109 & 0.054 & 0.007 & 0.007 \\
\hline & Lower $95 \%$ ci & 0.017 & 0.007 & 0.010 & 0.482 & 0.013 & 0.001 & $<0.001$ \\
\hline & Upper 95\% ci & 0.279 & 0.245 & 0.167 & 2.551 & 0.237 & 0.037 & 0.134 \\
\hline \multirow[t]{3}{*}{2014} & Prediction & 0.011 & 0.007 & 0.006 & 0.171 & 0.008 & 0.001 & 0.001 \\
\hline & Lower $95 \%$ ci & 0.001 & 0.001 & 0.001 & 0.033 & 0.001 & $<0.001$ & $<0.001$ \\
\hline & Upper 95\% ci & 0.079 & 0.065 & 0.048 & 0.897 & 0.069 & 0.010 & 0.029 \\
\hline \multirow[t]{3}{*}{2015} & Prediction & 0.006 & 0.004 & 0.004 & 0.102 & 0.005 & 0.001 & 0.001 \\
\hline & Lower $95 \% \mathrm{ci}$ & 0.001 & $<0.001$ & $<0.001$ & 0.015 & $<0.001$ & $<0.001$ & $<0.001$ \\
\hline & Upper $95 \%$ ci & 0.060 & 0.045 & 0.036 & 0.675 & 0.051 & 0.007 & 0.020 \\
\hline \multirow[t]{3}{*}{2016} & Prediction & 0.024 & 0.015 & 0.014 & 0.379 & 0.019 & 0.002 & 0.002 \\
\hline & Lower $95 \%$ ci & 0.004 & 0.002 & 0.002 & 0.095 & 0.003 & $<0.001$ & $<0.001$ \\
\hline & Upper $95 \%$ ci & 0.142 & 0.116 & 0.080 & 1.514 & 0.117 & 0.017 & 0.054 \\
\hline \multirow[t]{3}{*}{2017} & Prediction & 0.032 & 0.020 & 0.019 & 0.514 & 0.025 & 0.003 & 0.003 \\
\hline & Lower $95 \%$ ci & 0.004 & 0.002 & 0.003 & 0.079 & 0.003 & $<0.001$ & $<0.001$ \\
\hline & Upper $95 \%$ ci & 0.273 & 0.178 & 0.121 & 3.360 & 0.189 & 0.026 & 0.082 \\
\hline
\end{tabular}




\subsection{Proxy for starry ray mortality rate}

\subsubsection{Literature scan}

Ellis et al. (2017) provide a review of short-term discard survival studies of elasmobranchs and conclude that "Discard survival of elasmobranchs varies with a range of biological attributes (e.g. species, size, sex and mode of gill ventilation) as well as the range of factors associated with capture (e.g. gear type, soak time, catch mass and composition, handling practices and the degree of exposure to air and any associated change in ambient temperature)". A number of the presented studies, all executed in the NW Atlantic Ocean, provide information on the short-term survival rate of skates, including the starry ray (Benoît et al., 2012; Mandelman et al., 2013). Key findings from Benoît et al. (2012) for the skate family (including Amblyraja radiata, Leuocoraja ocellata, Malocoraja senta) caught within the bottom trawl fishery in the Gulf of St. Lawrence (Canada) were that $86.2 \%$ of the individuals survived the initial capture and handling process on board, and $10.6 \%$ of the individuals died whilst being held in tanks. Overall, this resulted in a discard survival of $75.6 \%$ after a 110 hour monitoring period. Mandelman et al. (2013) found a mortality rate of $66 \%$ for starry ray caught within the commercial otter trawl in the western North Atlantic after a 7 day monitoring period in the laboratory.

While most studies provide estimates of short-term survival, ideally monitoring should be for as long as it takes to explicitly observe the treatment induced mortality. A typical cumulative mortality curve has an asymptotic shape (Benoît et al. , 2013) and the experiments should continue until the mortality approaches the asymptote (ICES, 2014). A Dutch study (Schram \& Molenaar, 2018) quantitatively estimated the longer-term discard survival probability of flatfish (sole, plaice, turbot and brill) and rays (thornback ray and spotted ray) in the North Sea pulse fishery. In total nine sea trips were executed on board three commercial pulse-trawlers with three trips per trawler. Sea trips were spread out over the year to account for potential seasonal variation in discards survival. Survival was monitored in captivity for 15-18 days. The survival monitoring period was of sufficient duration as mortality levelled out before the end of this period. Within all species, discards survival probabilities varied among sea trips. The overall discard survival probability of thornback ray in the $80 \mathrm{~mm}$ pulse-fishery with 2 hour tow duration and 20 minutes air exposure was estimated at 53\% (95\% ci 40\%-65\%). However, given the limited numbers of observations, this estimate should be considered and treated as a first indication of the actual discard survival probability in the $80 \mathrm{~mm}$ pulse-trawl fisheries. As survival probabilities were only observed during two sea trips ( $21 \%$ and $67 \%)$ for spotted ray (Raja montagui), no overall discards survival is given for this species.

\subsubsection{Proxy starry ray mortality rate}

The three MSC client fisheries in this report concerns three metiers of the otter trawl fisheries (i.e. OTB_DEF_70-90, OTB_DEF_100-119 and OTB_DEF_>120) and two metiers of the flyshoot fisheries (i.e. SSC_DEF_100-119 and SSC_DEF_> 120). As these two fisheries have different characteristics, we propose to work with separate proxies for starry ray mortality rate for the two fisheries.

\subsubsection{Otter trawl fishery}

One may expect that the survival probability of thornback ray can be similar to the starry ray as both species have similar physical characteristics, i.e. a rough upper skin. Therefore, the discard survival probability for thornback ray of 53\% from Schram \& Molenaar (2018) could be used as an indication of the starry ray survival rate for the otter trawl fisheries. However, the otter trawl fishery has different characteristics than the pulse fishery, i.e. the ottertrawl fishery has (i) a longer towing duration, (ii) larger catch size, (iii) lower towing speed, and (iv) extended catch sorting in comparison with the pulse fishery. These four variables all influence discards survival and should be taken into account when extrapolating the survival rate of thornback ray within the pulse fishery to the otter trawl fishery. The survival probability of thornback ray within the pulse fishery was established with a 
maximum air exposure on deck of $\sim 20$ minutes. The commissioning party noted that the catch sorting process on board the certified otter trawl fishery is on average approximately 60 minutes (30-90 minutes). This is 3 times longer than in the pulse fishery. Molenaar (pers. comm.) indicates that the first 60 minutes of air exposure on deck influence the ray survival rate. Where it is assumed that ray survival will decrease when a specimen is exposed for more than 30 minutes to air. It is therefore assumed that the discard survival rate for thornback ray in the second 30 minutes of catch processing is $\sim 27 \%(=53 \% / 2)$. Note that this is an arbitrary value.

So, when assuming that the discard survival rate for thornback ray is comparable with starry ray, survival would be $53 \%$ survival in the first 30 minutes of the sorting process and $27 \%(=53 \% / 2)$ in the second 30 minutes of the sorting process. This consequently results in a proxy for starry ray mortality rate of 0.60 (calculated as: $(1-(((53+27) / 2) / 100))$ ). Note that as there is no data to support this mortality rate, the proposed proxy should be used with extreme caution.

\subsubsection{Flyshoot fishery}

Under commercial conditions seiners are characterized by 60 minutes shoots. The majority of the capture process consists of fish herding by seining ropes towards the trawl path, only in the last 10 minutes of the capture process, fish enter the trawl and are exposed to mechanical injuries provoked by the trawl. As a result the fish is in a good condition when hauled on board. Catch sorting and thus air exposure is limited in the flyshoot fishery (less than 60 minutes; pers. comm. M. Soetaart, ILVO) and therefore survival is expected to be higher than in the otter trawl fishery and pulse trawl fishery. Recent survival research of the flyshoot metiers (pers. comm. J. Karlsen, DTU Aqua, unpublished data) indicated that up to $80 \%$ of discard survival of undersized plaice was found for this fishery. This survival rate is substantially higher than the survival rate found for plaice by Schram \& Molenaar (2018). Based on the plaice survival for flyshoot fisheries with air exposure less than 60 minutes a precautionary proxy of the mortality rate of starry ray is set at 0.20 (calculated as: $(1-(80 / 100))$ ). Note that as there is no data to support this mortality rate, the proposed proxy should be used with extreme caution. 
As an overlap is visible in the spatial distribution of the MSC certified otter trawl and flyshoot fisheries and starry ray and the survey indices show a declining trend, the effect of the fisheries on starry ray, which is defined as an Endangered, Threatened or Protected (ETP) species by the MSC, needed to be evaluated. The aim of this project is to provide a tool that can be used to estimate the impact of the three MSC client fisheries on the starry ray population. Where the three MSC client fisheries concern three metiers of the otter trawl fisheries (i.e. OTB_DEF_70-90, OTB_DEF_100-119 and OTB_DEF_>120) and two metiers of the flyshoot fisheries (i.e.. SSC_DEF_100-119 and SSC_DEF__ $>120$ ). In order to evaluate the impact of the three MSC client fisheries on the starry ray population, the following information is needed:

\section{STEP 1: What is the starry ray population size?}

The minimum annual weight of the starry ray population has been estimated based on data collected within the IBTS and BTS (Figure 10, Table 2). It must be noted that the presented results concern a minimum estimate of the starry population size as the model assumes a catchability of 1 , i.e. we assume all fish encountered by the gear are caught.

\section{STEP 2: What are the starry ray catches of the Dutch bottom-trawl and seine fishery?}

Starry ray discard estimates by trip for the existing DCF self-sampling and observer programme have been used to predict the starry ray discards rate (expressed in $\mathrm{kg} / \mathrm{day}$ and $\mathrm{kg} / \mathrm{kg}$ plaice landed) by year and metier (Tables 6-7). As it is assumed that starry ray is exclusively discarded (ICES, 2015), the model predictions refer to a starry ray catch rate rather than a starry ray discards rate.

STEP 3: What are the starry ray catches of the three MSC client fisheries?

In order to answer this question the starry ray catch rates that have been calculated in step 2 need to be converted to the three MSC client fisheries. The preferred method would be to use the relationship between the predicted catch rate (expressed in $\mathrm{kg} /$ days at sea) and the effort of the three MSC client fisheries by year and metier to estimate the total starry ray catch of the three MSC client fisheries. However, the commissioning party noted that it is difficult to supply the exact effort information of the three MSC client fisheries. Therefore, an alternative method, namely the relationship between the predicted catch rate (expressed in $\mathrm{kg} / \mathrm{kg}$ plaice landed) and plaice landings of the three MSC client fisheries by year and metier, is proposed to estimate the total starry ray catch of the three MSC client fisheries.

The total starry ray catch of the three MSC client fisheries can be calculated by year and metier using the relationship between the starry ray catch rate that has been calculated in step 2 (see also section 3.2.1) and effort or plaice information of the three MSC client fisheries (Equation 3 or Equation 4 in section 3.2.3).

\section{STEP 4: What is the impact of the three MSC client fisheries on the starry ray population?} Based on a literature scan a proxy for starry ray mortality rate of 0.60 is proposed for the otter trawl fishery and 0.20 is proposed for the flyshoot fishery. Note that these proxies should be used with extreme caution as they concern extrapolations from survival studies of other species and fisheries.

In order to estimate the impact of the three MSC client fisheries on the starry ray population, the total dead removal of starry ray first needs to be calculated:

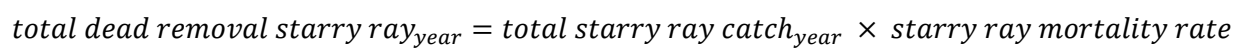

, where total starry ray catch is calculated in step 3 and mortality rate is 0.60 for the otter trawl fishery and 0.20 for the flyshoot fishery. Consequently the impact (expressed in \% removal of the estimated population size) of the fishery on the starry ray population can be calculated as: 
impact of the fishery $y_{\text {ear }}=\left(\right.$ total dead removal starry ray $_{\text {year }} /$ starry ray population size $\left._{\text {year }}\right) \times 100$ Equation 6 , starry ray population size is calculated in step 1. 


\section{Recommendations}

Based on this study we propose the following recommendations:

- Include fisheries dependent data in the population model (INLA) to improve the catchability estimates in the model.

- Increase the sampling coverage of the discards monitoring of the three MSC client fisheries.

- Execute field studies to determine the actual mortality rate of starry ray within the client fisheries. 
Wageningen Marine Research utilises an ISO 9001:2015 certified quality management system. This certificate is valid until 15 December 2021. The organisation has been certified since 27 February 2001. The certification was issued by DNV GL.

Furthermore, the chemical laboratory at IJmuiden has NEN-EN-ISO/IEC 17025:2005 accreditation for test laboratories with number L097. This accreditation is valid until $1^{\text {th }}$ of April 2021 and was first issued on 27 March 1997. Accreditation was granted by the Council for Accreditation. The chemical laboratory at IJmuiden has thus demonstrated its ability to provide valid results according a technically competent manner and to work according to the ISO 17025 standard. The scope (L097) of de accredited analytical methods can be found at the website of the Council for Accreditation (www.rva.nl).

On the basis of this accreditation, the quality characteristic $Q$ is awarded to the results of those components which are incorporated in the scope, provided they comply with all quality requirements. The quality characteristic $Q$ is stated in the tables with the results. If, the quality characteristic $Q$ is not mentioned, the reason why is explained.

The quality of the test methods is ensured in various ways. The accuracy of the analysis is regularly assessed by participation in inter-laboratory performance studies including those organized by QUASIMEME. If no inter-laboratory study is available, a second-level control is performed. In addition, a first-level control is performed for each series of measurements.

In addition to the line controls the following general quality controls are carried out:

- Blank research.

- Recovery.

- Internal standard

- Injection standard.

- Sensitivity.

The above controls are described in Wageningen Marine Research working instruction ISW 2.10.2.105. If desired, information regarding the performance characteristics of the analytical methods is available at the chemical laboratory at IJmuiden.

If the quality cannot be guaranteed, appropriate measures are taken. 


\section{Appendix I}

Table I.1: List of Dutch bottom-trawl and seine metiers sampled in 2000-2017. These have been classified according to the European Union (EU) definitions (2008/949/EC Appendix IV) requiring information about gear type (i.e. demersal beam - TBB; ottertrawl - OTB/OTT and Scottish seine SSC; level 4), target species assemblage (i.e. demersal fish - DEF, mixed crustaceans and demersal fish - MCD; level 5), mesh size ranges (in mm; level 6) (Table taken from Verkempynck et al., 2018)

\begin{tabular}{lccc}
\hline Level 4 & Level 5 & Level 6 & Assigned metier \\
Gear type & Target assemblage & Mesh size & \\
\hline OTB $* * *$ & DEF & $\geq 120$ & OTB_DEF_> $=120$ \\
OTB $* * *$ & DEF & $100-119$ & OTB_DEF_100-119 \\
OTB $* * *$ & DEF & $70-99$ & OTB_DEF_70-99 \\
OTB $* * *$ & MCD & $70-99$ & OTB_MCD_70-99 \\
SSC & DEF & $\geq 120$ & SSC_DEF_> $=120$ \\
SSC & DEF & $100-119$ & SSC_DEF_100-119 \\
SSC & DEF & $70-99$ & SSC_DEF_70-99 \\
TBB & DEF & $\geq 120$ & TBB_DEF_> $=120$ \\
TBB & DEF & $100-119$ & TBB_DEF_100-119 \\
TBB $(>300 \mathrm{hp}) *$ & DEF & $70-99 * *$ & TBB_DEF_70-99_G300hp \\
TBB $(\leq 300 \mathrm{hp}) *$ & DEF & $70-99 * *$ & TBB_DEF_70-99_S300hp \\
\hline
\end{tabular}

* Note that the TBB metier is further subdivided on a national level in the Netherlands based on engine size (horse power, hp): vessels with $\leq 300 \mathrm{hp}$ engine power are so called "Eurocutters". $* *$ Note that due to regulation vessels within this metier do not fish with a mesh size $<80 \mathrm{~mm}$. *** Note that in this report all OTB should be read as OTB/OTT/QUA, as in logbook in the Dutch data otter trawl (OTB), pair trawl (OTT), and quadrig (QUA) gear can used interchangeably. 
Table II.1. Fixed effects parameter estimates of selected population model.

\begin{tabular}{|c|c|c|c|c|c|c|}
\hline Effect & Mean & $\mathrm{Sd}$ & 0.025 quant & $0.5 q u a n t$ & 0.975 quant & Mode \\
\hline Intercept & 1.7277 & 0.6943 & 0.3593 & 1.7290 & 3.0872 & 1.7315 \\
\hline Year 1981 & 0.7819 & 0.2868 & 0.2207 & 0.7813 & 1.3464 & 0.7800 \\
\hline Year 1982 & -0.4986 & 0.3564 & -1.1984 & -0.4987 & 0.2007 & -0.4987 \\
\hline Year 1983 & 1.0164 & 0.3689 & 0.2940 & 1.0156 & 1.7425 & 1.0140 \\
\hline Year 1984 & 1.6693 & 0.3980 & 0.8901 & 1.6683 & 2.4530 & 1.6666 \\
\hline Year 1985 & 1.0915 & 0.4309 & 0.2473 & 1.0908 & 1.9392 & 1.0893 \\
\hline Year 1986 & 1.3576 & 0.4571 & 0.4613 & 1.3570 & 2.2564 & 1.3558 \\
\hline Year 1987 & 1.7487 & 0.4791 & 0.8086 & 1.7482 & 2.6901 & 1.7474 \\
\hline Year 1988 & 0.9988 & 0.5051 & 0.0077 & 0.9983 & 1.9914 & 0.9974 \\
\hline Year 1989 & 1.8331 & 0.5226 & 0.8076 & 1.8326 & 2.8600 & 1.8318 \\
\hline Year 1990 & 1.7997 & 0.5409 & 0.7384 & 1.7992 & 2.8629 & 1.7982 \\
\hline Year 1991 & 1.9641 & 0.5527 & 0.8801 & 1.9634 & 3.0509 & 1.9621 \\
\hline Year 1992 & 1.5510 & 0.5701 & 0.4323 & 1.5504 & 2.6715 & 1.5495 \\
\hline Year 1993 & 1.8383 & 0.5852 & 0.6901 & 1.8378 & 2.9885 & 1.8367 \\
\hline Year 1994 & 1.1111 & 0.6016 & -0.0687 & 1.1104 & 2.2940 & 1.1090 \\
\hline Year 1995 & 1.5524 & 0.6152 & 0.3455 & 1.5517 & 2.7619 & 1.5505 \\
\hline Year 1996 & 1.0716 & 0.6285 & -0.1627 & 1.0713 & 2.3062 & 1.0708 \\
\hline Year 1997 & 0.9354 & 0.6419 & -0.3254 & 0.9352 & 2.1960 & 0.9349 \\
\hline Year 1998 & 1.2157 & 0.6512 & -0.0625 & 1.2152 & 2.4954 & 1.2143 \\
\hline Year 1999 & 1.3613 & 0.6606 & 0.0648 & 1.3608 & 2.6595 & 1.3598 \\
\hline Year 2000 & 1.3117 & 0.6719 & -0.0078 & 1.3114 & 2.6313 & 1.3109 \\
\hline Year 2001 & 1.0833 & 0.6814 & -0.2553 & 1.0832 & 2.4214 & 1.0829 \\
\hline Year 2002 & 0.9602 & 0.6904 & -0.3957 & 0.9599 & 2.3162 & 0.9594 \\
\hline Year 2003 & 0.9562 & 0.6988 & -0.4155 & 0.9557 & 2.3293 & 0.9549 \\
\hline Year 2004 & 0.9926 & 0.7070 & -0.3953 & 0.9921 & 2.3816 & 0.9913 \\
\hline Year 2005 & 0.9155 & 0.7151 & -0.4884 & 0.9151 & 2.3205 & 0.9143 \\
\hline Year 2006 & 0.7303 & 0.7236 & -0.6905 & 0.7299 & 2.1520 & 0.7292 \\
\hline Year 2007 & 0.9616 & 0.7310 & -0.4736 & 0.9612 & 2.3979 & 0.9604 \\
\hline Year 2008 & 0.9320 & 0.7381 & -0.5167 & 0.9314 & 2.3827 & 0.9303 \\
\hline Year 2009 & 0.3679 & 0.7463 & -1.0977 & 0.3676 & 1.8338 & 0.3671 \\
\hline Year 2010 & 0.1554 & 0.7537 & -1.3252 & 0.1552 & 1.6355 & 0.1548 \\
\hline Year 2011 & 0.2100 & 0.7595 & -1.2817 & 0.2097 & 1.7016 & 0.2093 \\
\hline Year 2012 & 0.5075 & 0.7637 & -0.9927 & 0.5073 & 2.0075 & 0.5069 \\
\hline Year 2013 & 0.1190 & 0.7708 & -1.3952 & 0.1188 & 1.6325 & 0.1185 \\
\hline Year 2014 & 0.5495 & 0.7749 & -0.9721 & 0.5491 & 2.0720 & 0.5483 \\
\hline Year 2015 & 0.7741 & 0.7793 & -0.7560 & 0.7736 & 2.3052 & 0.7729 \\
\hline Year 2016 & 0.6386 & 0.7855 & -0.9046 & 0.6384 & 2.1813 & 0.6381 \\
\hline Year 2017 & 0.5372 & 0.8013 & -1.0373 & 0.5371 & 2.1103 & 0.5371 \\
\hline Survey NSIBTS & -1.9948 & 0.0606 & -2.1140 & -1.9947 & -1.8762 & -1.9945 \\
\hline Log(surface) & 1.1117 & 0.0614 & 0.9912 & 1.1116 & 1.2323 & 1.1150 \\
\hline
\end{tabular}


Table II.2. Hyperparameter estimates of selected population model.

\begin{tabular}{|c|c|c|c|c|c|c|}
\hline & mean & sd & $0.025 q u a n t$ & $0.5 q u a n t$ & $0.975 q u a n t$ & mode \\
\hline Size NB obs & 0.6216 & $1.05 \mathrm{E}-02$ & 0.5995 & 0.6223 & 0.641 & 0.6249 \\
\hline Theta 1 for $w$ & 2.4559 & $5.12 \mathrm{E}-02$ & 2.3453 & 2.4604 & 2.55 & 2.4768 \\
\hline Theta2 for $\mathrm{w}$ & -4.3525 & $6.20 \mathrm{E}-02$ & -4.4592 & -4.3583 & -4.22 & -4.3796 \\
\hline GroupRho for w & 0.9633 & $2.90 \mathrm{E}-03$ & 0.9581 & 0.9632 & 0.969 & 0.9625 \\
\hline Precision for Depth & 49109 & $2.68 E+04$ & 16481 & 42850 & $1.18 \mathrm{E}+05$ & 33143 \\
\hline
\end{tabular}

Table II.3. Parameter estimates of selected catch model using starry ray discards rate expressed in $\mathrm{kg} /$ day as response variable.

\begin{tabular}{|c|c|c|c|c|}
\hline Effect & estimate & Std. error & $z$ value & $\operatorname{Pr}(>|z|)$ \\
\hline Intercept & 2.8468 & 0.8304 & 3.428 & $<0.001$ \\
\hline Year 2010 & 1.6756 & 0.7782 & 2.153 & 0.031 \\
\hline Year 2011 & -1.7174 & 0.8315 & -2.066 & 0.039 \\
\hline Year 2012 & 1.7559 & 0.7697 & 2.281 & 0.023 \\
\hline Year 2013 & 2.3823 & 0.7781 & 3.062 & 0.002 \\
\hline Year 2014 & 2.7597 & 0.7558 & 3.651 & $<0.001$ \\
\hline Year 2015 & 2.4425 & 0.7585 & 3.220 & 0.001 \\
\hline Year 2016 & 3.1723 & 0.7577 & 4.187 & $<0.001$ \\
\hline Year 2017 & 2.8510 & 0.7554 & 3.774 & $<0.001$ \\
\hline Metier OTB_DEF_70-99 & -2.7493 & 0.7695 & -3.573 & $<0.001$ \\
\hline Metier OTB_MCD_70-99 & -2.3094 & 0.6953 & -3.321 & $<0.001$ \\
\hline Metier SSC_DEF_> $=100$ & -0.6268 & 1.0320 & -0.607 & 0.544 \\
\hline Metier TBB_DEF_> $=100$ & -0.6876 & 0.7744 & -0.888 & 0.375 \\
\hline Metier TBB_DEF_70-99_G300hp & -3.6550 & 0.5871 & -6.226 & $<0.001$ \\
\hline Metier TBB_DEF_70-99_S300hp & -5.9328 & 0.6977 & -8.503 & $<0.001$ \\
\hline
\end{tabular}

Table II.4. Parameter estimates of selected catch model using starry ray discards rate expressed in $\mathrm{kg} / \mathrm{kg}$ plaice landed as response variable.

\begin{tabular}{|c|c|c|c|c|}
\hline Effect & estimate & Std. error & $z$ value & $\operatorname{Pr}(>|z|)$ \\
\hline Intercept & -4.7969 & 2.4855 & -1.930 & 0.054 \\
\hline Year 2010 & 0.9977 & 2.6192 & 0.381 & 0.703 \\
\hline Year 2011 & -1.9973 & 3.8183 & -0.523 & 0.601 \\
\hline Year 2012 & 1.8982 & 2.4558 & 0.773 & 0.440 \\
\hline Year 2013 & 2.1209 & 2.4519 & 0.865 & 0.387 \\
\hline Year 2014 & 0.2497 & 2.5641 & 0.097 & 0.922 \\
\hline Year 2015 & -0.2672 & 2.6118 & -0.102 & 0.919 \\
\hline Year 2016 & 1.0467 & 2.5121 & 0.417 & 0.677 \\
\hline Year 2017 & 1.3520 & 2.5489 & 0.530 & 0.596 \\
\hline Metier OTB_DEF_70-99 & -0.4822 & 1.0516 & -0.459 & 0.647 \\
\hline Metier OTB_MCD_70-99 & -0.5136 & 0.9221 & -0.557 & 0.578 \\
\hline Metier SSC_DEF_> $=100$ & 2.7795 & 0.7303 & 3.806 & $<0.001$ \\
\hline Metier TBB_DEF_> $=100$ & -0.2348 & 0.9433 & -0.249 & 0.803 \\
\hline Metier TBB_DEF_70-99_G300hp & -2.3439 & 1.0448 & -2.243 & 0.025 \\
\hline Metier TBB_DEF_70-99_S300hp & -2.2571 & 1.5950 & -1.415 & 0.157 \\
\hline
\end{tabular}




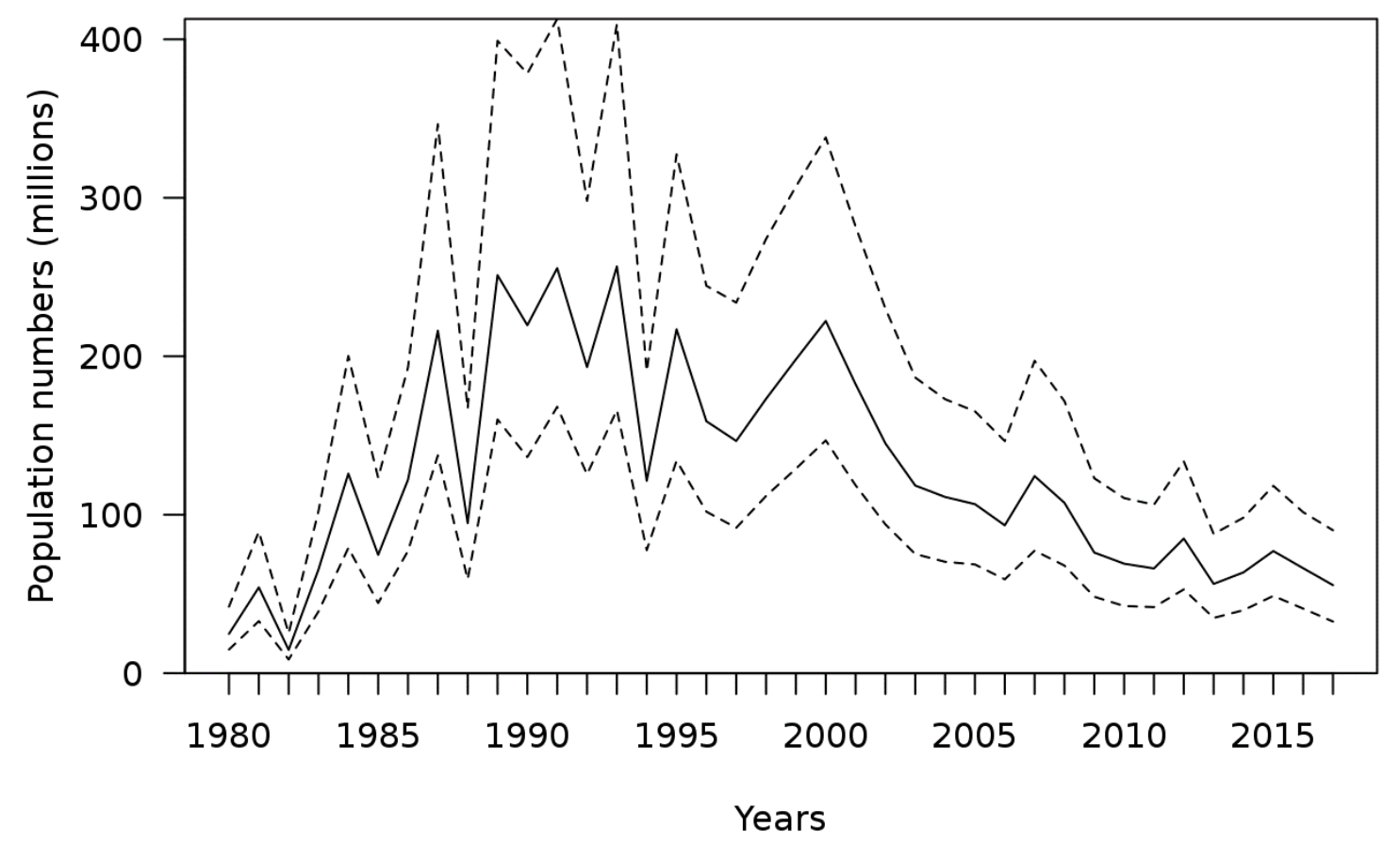

Figure II.1. Model estimates of starry ray population numbers (median - solid line) and corresponding uncertainty ( 0.025 quant and 0.975 quant - lower and upper dotted line) expressed in millions.

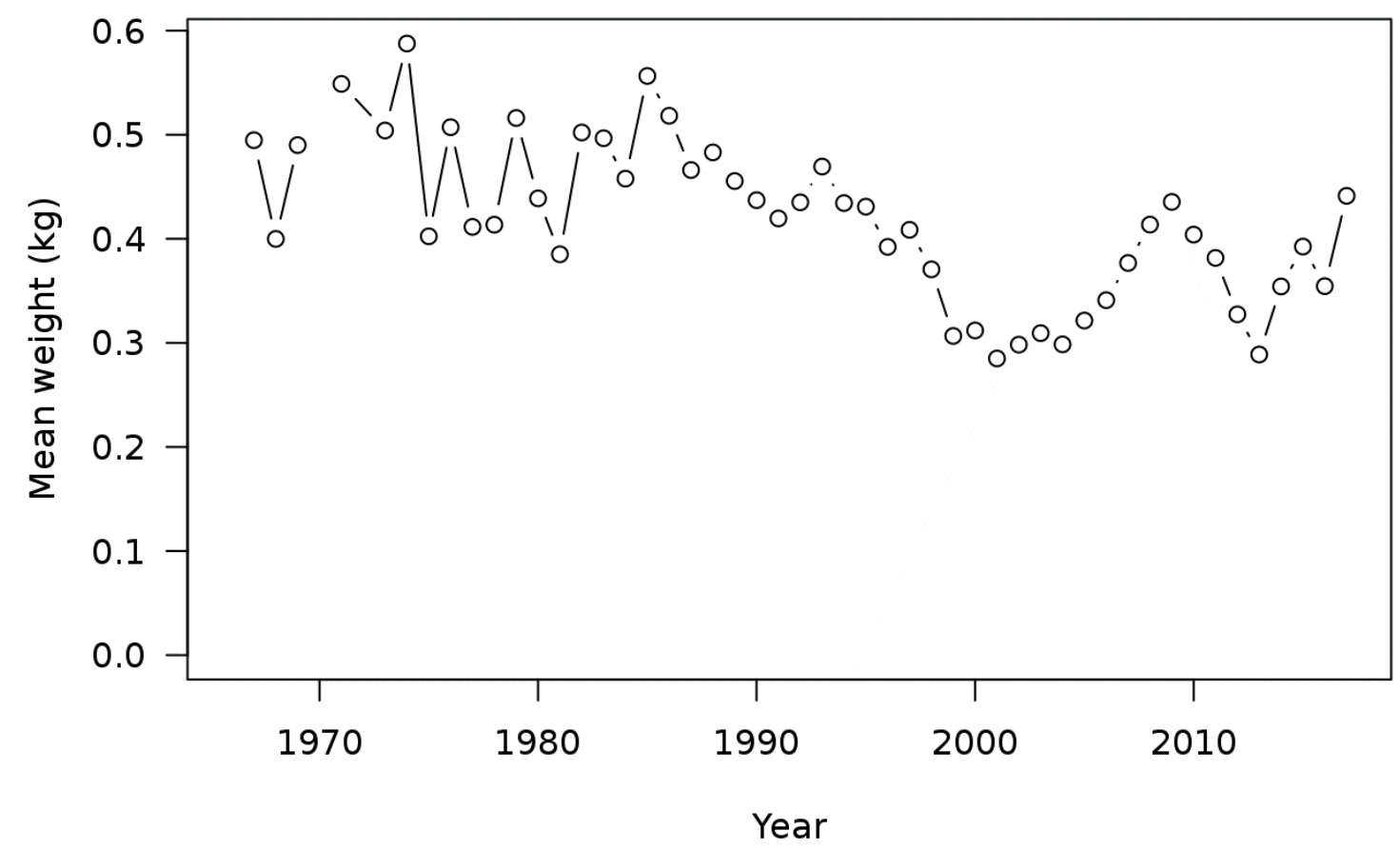

Figure II.2. Mean weight $(\mathrm{kg})$ of starry ray individual by year. 


\section{References}

Bedford, B.C., L.E. Woolner, B.W. Jones. 1986. Length-weight relationships for commercial fish species and conversion factors for various presentations. Fisheries Research Data Report, MAFF Directorate of Fisheries Research, 10. 41 pp.

Benoît, H.P, T. Hurlbut, J. Chassé \& I.D. Jonsen. 2012. Estimating fishery-scale rates of discard mortality using conditional reasoning. Fisheries Research 125: 318-330.

Benoît, H. P., S. Plante, M. Kroiz, \& T. Hurlbut. 2013. A comparative analysis of marine fish species susceptibilities to discard mortality: effects of environmental factors, individual traits, and phylogeny. ICES Journal of Marine Science, 70: 99-113.

Ellis, J. R., S.R. McCully Phillips \& F. Poisson. 2017. A review of capture and post-release mortality of elasmobranchs. Journal of Fish Biology, 90: 653-722.

ICES. 2014. Report of the Workship on Methods for Estimating Discard Survival (WKMEDS), 17-21 February 2014, ICES HQ, Copenhagen, Denmark. ICES CM 2014/ACOM: 51. 114 pp.

ICES. 2015. ICES Advice on fishing opportunities, catch and effort Greater North Sea Ecoregion. 6.3.50 Starry Ray (Amblyraja radiata) in Subareas II and IV and Division IIIa (Norwegian Sea, North Sea, Skagerrak and Kattegat). http://www.ices.dk/sites/pub/Publication\%20Reports/Advice/2015/2015/rjr-234.pdf

ICES. 2018. Report of the Working Group on Elasmobranch Fishes (WGEF), 19-28 June 2018, Lisbon, Portugal. ICES CM 2018/ACOM:16. 1306 pp.

Mandelman, J.W., A.M. Cicia, G.W. Ingram Jr., W.B. Driggers III, K.M. Coutre \& J.A. Sulikowski. 2013. Short-term post-release mortality of skates (family Rajidae) discarded in a western North Atlantic commercial otter trawl fishery. Fisheries Research 139: 76.84.

Rue, H., S. Martino, N. Chopin. 2009. Approximate Bayesian Inference for latent Gaussian models by using integrated nested Laplace approximations. Journal of the Royal Statistical Society. Series B (Statistical Methodology) Vol. 71, No.2., pp. 319-392.

Schram, E. \& P. Molenaar. 2018. Discards survival probabilities of flatfish and rays in North Sea pulsetrawl fisheries. Wageningen, Wageningen Marine Research (University \& Research centre), Wageningen Marine Research report C037/18: 39 pp.

Verkempynck, R., H. van Overzee, M. Dammers. 2018. Discard self-sampling of Dutch bottom-trawl and seine fisheries in 2014-2016. CVO Report 18.007. 102 pp.

Verkempynck, R., C. Chen, A.T.M. van Helmond, S.S. UhImann. In prep. Comparison of the Dutch observer and self-sampling discards data.

Wood, S.N. 2006. Generalized Additive Models: An Introduction with R, CRC. 


\section{Justification}

Report C033/19

Project Number: 4311100069

The scientific quality of this report has been peer reviewed by a colleague scientist and a member of the Management Team of Wageningen Marine Research

Approved: $\quad$ Serdar Sakinan

Researcher

Signature:

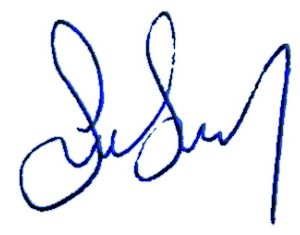

Date:

$4^{\text {th }}$ of April 2019

Approved: Jakob Asjes

Manager Integration

Signature:

Date:

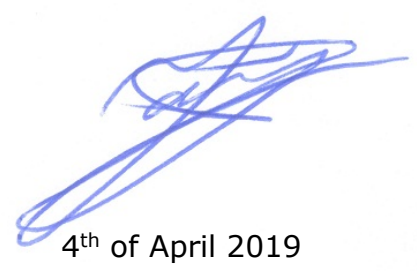


Wageningen Marine Research

$\mathrm{T}+31(0) 317480900$

E: marine-research@wur.nl

www.wur.eu/marine-research

Visitors' address

- Ankerpark 271781 AG Den Helder

- Korringaweg 7, 4401 NT Yerseke

- Haringkade 1, 1976 CP IJmuiden
Wageningen Marine Research is the Netherlands research institute established to provide the scientific support that is essential for developing policies and innovation in respect of the marine environment, fishery activities, aquaculture and the maritime sector.

\section{Wageningen University \& Research:}

is specialised in the domain of healthy food and living environment.

\section{The Wageningen Marine Research vision}

'To explore the potential of marine nature to improve the quality of life'

\section{The Wageningen Marine Research mission}

- To conduct research with the aim of acquiring knowledge and offering advice on the sustainable management and use of marine and coastal areas.

- Wageningen Marine Research is an independent, leading scientific research institute

Wageningen Marine Research is part of the international knowledge organisation Wageningen UR (University \& Research centre). Within Wageningen UR, nine specialised research institutes of the Stichting Wageningen Research Foundation have joined forces with Wageningen University to help answer the most important questions in the domain of healthy food and living environment. 